\title{
The Role of Leverage in Firm Solvency: Evidence From Bank Loans
}

\author{
Emilia Bonaccorsi di Patti ${ }^{1}$ - Alessio D'Ignazió ${ }^{2}$. \\ Marco Gallo $^{3}$. Giacinto Micucci ${ }^{4}$
}

Received: 17 December 2014 / Accepted: 8 April 2015 / Published online: 29 April 2015

(C) Società Italiana degli Economisti (Italian Economic Association) 2015

\begin{abstract}
The two recessions that hit Italy since the end of 2008 have raised substantially the share of non-performing loans to businesses in banks' portfolios. In this paper we evaluate to what extent the deterioration of credit quality resulted not only from the drop in firms' sales during the contraction of economic activity, but also from the level of firms financial debt at the onset of the first recession. Our results show that, ceteris paribus, a $10 \%$ points increase in leverage is associated with almost a $1 \%$ point higher probability of default. Moreover, the adverse impact of a drop in sales on firm solvency is almost four times larger for firms in the highest quartile of the leverage distribution than for firms in the first quartile. These findings confirm that the firms' financial structure can be a powerful amplifier of macroeconomic shocks. A higher level of borrowers' leverage reduces their resilience during a recession, and this in turn weakens the balance-sheets of banks and their ability to provide credit.
\end{abstract}

Keywords Leverage $\cdot$ Nonperforming loans · Corporate default · Insolvency

Electronic supplementary material The online version of this article (doi:10.1007/s40797-015-0014-7) contains supplementary material, which is available to authorized users.

We thank Alessandro Carretta, Giorgio Gobbi, Alberto Franco Pozzolo, Paolo Sestito, and an anonymous referee for valuable comments and suggestions. The usual disclaimer applies. The views expressed herein are those of the authors and do not necessarily reflect those of the Bank of Italy or the Eurosystem.

$凶$ Alessio D'Ignazio

alessio.dignazio@bancaditalia.it

1 Bank of Italy, Financial Stability Directorate, Rome, Italy

2 Bank of Italy, Structural Economic Analysis Directorate, Via Nazionale 91, 00184 Rome, Italy

3 Bank of Italy, Florence Branch, Florence, Italy

4 Bank of Italy, Ancona Branch, Ancona, Italy 
JEL Classification $\mathrm{G} 01 \cdot \mathrm{G} 21 \cdot \mathrm{G} 31 \cdot \mathrm{G} 33$

\section{Introduction}

The financial crisis of 2007-2008 erupted after a long expansionary cycle in advanced economies, characterized by rapid credit growth and, in some countries, bubbles in asset and real estate markets. In Italy the sustained growth in bank lending reflected primarily the transformation of the banking industry following the reforms of the 1990s and the decline in spreads due to the creation of the euro. The ratio of bank credit to GDP increased from 40 to $55 \%$ between 2000 and 2007. In the same period the aggregate leverage ratio of nonfinancial corporations, defined as the ratio between financial debts and the sum of financial debts and equity at market value, went up from less than $35 \%$ to about $42 \%$ (Fig. 1).

In the second half of 2008, after the default of Lehman Brothers, the global recession was transmitted to the Italian economy. A weak recovery in 2010 was interrupted by the sovereign debt crisis, which triggered a second recession starting in the third quarter of 2011. As shown in Fig. 2, the cyclical conditions had a severe impact on the solvency of nonfinancial firms and on the quality of bank loan portfolios, with the rate of newly defaulting loans climbing to historically high levels.

From a macroprudential policy perspective, an important question that arises is to what extent the financial structure of firms increases their fragility to negative macroeconomic shocks. In economies in which banks are heavily exposed to the domestic nonfinancial sector through traditional lending, high levels of debt in the nonfinancial

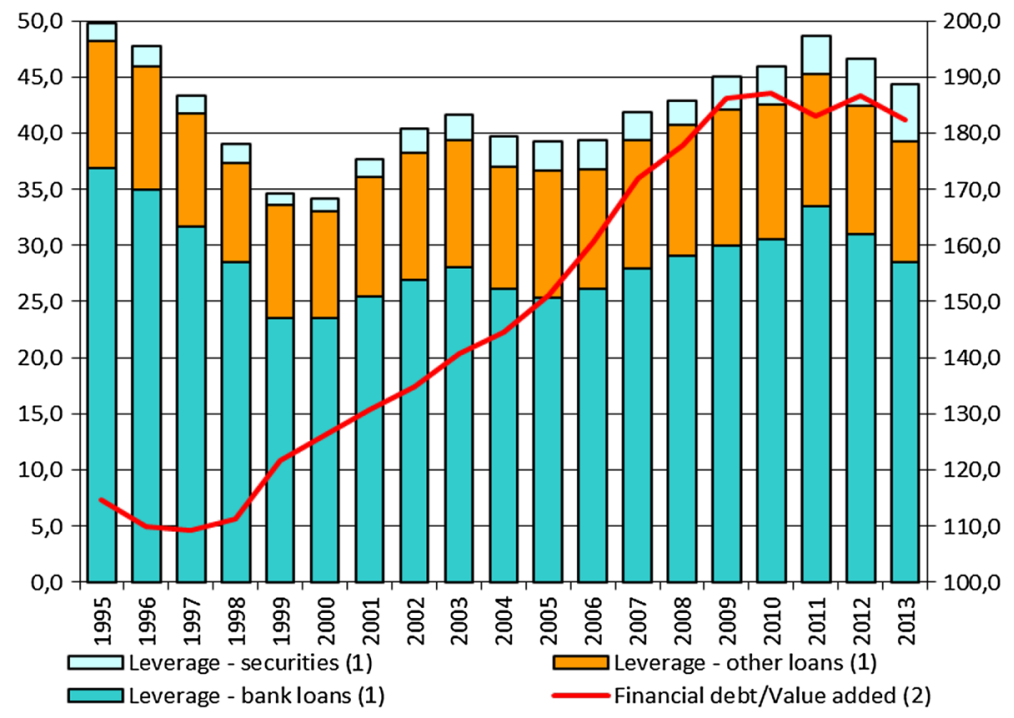

Fig. 1 Corporate debt (the data refer to the non-financial corporations sector). Note All values are percentages. Data from Bank of Italy and Istat. Data do not reflect SEC 2010 (Annual Report of the Bank of Italy 2014). (1) Left-hand scale leverage is calculated as the ratio of financial debt to the sum of financial debt and shareholders' equity at market prices. (2) Right-hand scale 


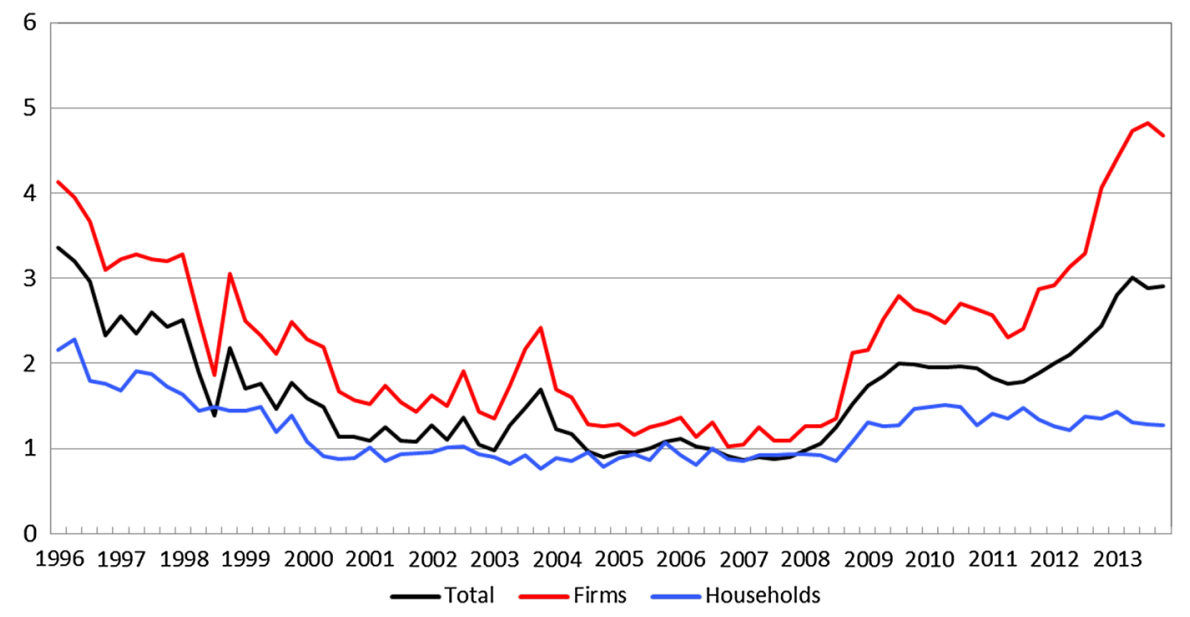

Fig. 2 Ratio of new bad debts to outstanding loans (quarterly flow of adjusted bad debts in relation to the stock of loans at the end of the previous quarter; annual data up to the fourth quarter of 1995. Seasonally adjusted where necessary and annualized). Sources: supervisory statistical reports and Central Credit Register. Note All values are percentages

sector can exacerbate the impact of a recession on bank health. As suggested by the literature on the procyclicality of lending standards, the expansion of debt could itself be the result of lax lending standards [see for example Dell'Ariccia and Marquez (2006); Saurina and Jimenez (2006)]. During an expansionary phase banks tend to extend loans to riskier borrowers because they underestimate how credit risk changes when the macroeconomic conditions change (see Berger and Udell 2004).

In this paper we focus on two issues: (1) we investigate if and how leverage increases the probability of default of firms when they are hit by a shock, (2) we quantify this effect based on 2008-2012 data, a period of severe stress on firms and banks in Italy.

Our empirical model is a reduced form logit model of the probability of default. We estimate the model using a very large sample of Italian nonfinancial firms that borrow from banks and use a definition of insolvency based on data from the Italian Credit Register. In essence, a firm is considered defaulted if it is unable to repay its bank debts. Thanks to this definition we can include a large number of small firms that do not issue bonds, and for which data on defaults would not be available from market sources.

Our main findings are the following. The drop in sales is the variable that better explains default during the period 2008-2012. Nevertheless, the leverage of firms at the onset of the first recession has a substantial, independent, impact on the default probability, controlling for the negative shock to sales. The effect of leverage is twofold. Not only leverage increases the default rate on average, but it also raises the sensitivity of the probability of default to the drop in sales, i.e. it reduces the resilience of firms. In economic terms, these effects are significant: a drop in sales of $10 \%$ points raised the default probability by about $6 \%$ points for firms that in 2008 were in the top quartile of leverage (i.e. it doubles defaults with respect to the sample mean); the same shock raised the default probability by about $1.7 \%$ points for firms in the lowest quartile of leverage (an increase by a quarter with respect to the sample mean). 
Our study is related to two strands of literature. The first is the literature on the determinants of corporate insolvency. This literature analyzes the determinants of corporate default focusing on ex ante balance sheet variables to predict subsequent default, typically 1 year later, following the seminal work of Altman (1968). These studies typically use small samples of large, often listed, firms and find that leverage is a predictor of insolvency. We contribute to this literature by using a very large data set of small and medium enterprises, and by applying a very general definition of insolvency that does not depend on features of the legal system in the country of the sample.

The second strand of literature is the one investigating how firm defaults vary with cyclical conditions. Although we do not focus on fluctuations in economic activity, our analysis is related to this literature because we propose to use a firm level measure of the negative shock resulting from adverse macroeconomic conditions. We share with the most recent studies the use of credit register or internal bank data on defaults (e.g. Carling et al. 2007; Bonfim 2009). To our knowledge, there is no study on Italy that analyzes firm defaults during 2008-2012 using credit register data.

\subsection{Related Literature}

An extensive literature investigates the determinants of corporate default. There are two main strands of literature. The first strand employs statistical reduced-form models, primarily for the purpose of prediction of bankruptcy, while other studies follow a structural approach to derive probabilities of default based on the seminal work of Merton (1974). We briefly discuss only the former because it is directly related to the simple approach followed in this paper. While the statistical models tend to be ad hoc and are not grounded on a specific theory they have the doubtless advantage of being applicable to data on privately held firms.

Statistical methods differ across the following three dimensions: the type of model, the type of variables included to explain default, the definition of default. The earlier models were based on linear discriminant analysis (see Altman 1968) to classify observations into defaulting and non defaulting, based on a linear combination of firm characteristics. Later studies rely on logistic or probit regression methods because they are characterized by less stringent assumptions than the linear discriminant model (Tabachnick and Fidell 1996).

In terms of the variables used to predict default, the literature differs according to whether market variables or accounting data are used. Earlier models, such as Altman (1968) and Ohlson (1980), use accounting variables. More recent studies add variables based on equity market data to the standard accounting measures used in the earlier literature to improve the predictive power of the models (e.g. Shumway 2001; Campbell et al. 2008).

Other studies explore the role of industry and macroeconomic factors. For example, Chava and Jarrow (2004) add industry effects to their hazard model and find that their inclusion significantly improves the predictive ability of the model. Graham et al. (2011) study the factors that contributed to business insolvency during the Great Depression. They find that firms with more debt and lower bond ratings became 
financially distressed more frequently during the Depression. Using Portuguese data, Bonfim (2009) confirms the hypothesis that in periods of economic growth there is a tendency towards excessive risk-taking and such imbalances become apparent only when economic growth slows down. She finds that while default mainly depends on firm specific financial characteristics, their interactions with macroeconomic conditions should be taken into account, as they improve the fit of the model. Carling et al. (2007) show that models taking into account macroeconomic variables are able to account not only for the ranking of firms' default risk, but also for the absolute level of risk.

While the earlier studies usually adopt a definition of insolvency that is based either on bankruptcy filings or information drawn from rating agencies or other market sources, ${ }^{1}$ some of the most recent analyses use indicators of default based on credit registers or internal bank ratings. Bonfim (2009) uses the Banco de Portugal Central Credit Register data, and a firm is considered defaulted if it has credit overdue; Carling et al. (2007) use credit data from a major Swedish bank: customers are considered defaulted if principal or interest payments are 60 days overdue, and a bank official has to make a judgement and reach the conclusion that any such payment is unlikely to occur in the future. Behr and Güttler (2007) estimate the probability of default for German SMEs, using data from a major German bank engaged in financing small and medium enterprises, while Fidrmuc and Hainz (2010) analyze the data from a Slovakian commercial bank. Finally, McCann and McIndoe-Calder (2012) study Irish SMEs' probability of default using Credit Register data: a firm is considered defaulted if it has loans 90 days past due. A disadvantage of analyses based on the data of one bank is that the results could be influenced by individual policies of the institution or its financial conditions.

\section{Data}

The first source of our data is the universe of Italian limited liability companies reported in the database Cerved. Only a subset of firms in Cerved report information on financial debt. We restrict our analysis to those that have such information for 2007 or 2008 and matched data with the records of borrowers in the Central credit register (CR) in 2008.

The CR reports, for each Italian credit institution (banks and specialized financial companies), all loans and guarantees to resident borrowers above a given threshold (75,000 euros before 2009 and 30,000 thereafter). Outstanding loans can be performing, past-due, restructured, substandard or bad. There is no threshold for reporting bad loans. A loan becomes bad if the lender deems the borrower irreversibly unable to repay its debt after having assessed his/her overall financial conditions. Therefore, late

\footnotetext{
1 Some studies use credit ratings rather than actual defaults as dependent variable (Kaplan and Urwitz 1979; Blume et al. 1998; Molina 2005). In some cases information from multiple sources is combined to have better coverage of cases of financial distress. Campbell et al. (2008) combine cases in which the firm files for bankruptcy with data on failures defined more broadly to include bankruptcies, financially driven delistings, or "default" ratings issued by a leading credit rating agency.
} 
payments are not sufficient to be considered defaulted, which requires an assessment on the prospects of the firm.

Since we focus on borrowers rather than individual loans/relationships, we use information on client status constructed by the CR over all the reported relationships for each borrower. As described in the ESM Data Appendix, the status of a borrower is defined on the basis of (1) the status of each of the credit relationships the borrower may have, and (2) materiality of exposures. The intuition is that a borrower should not be considered defaulted if only a very small fraction of its exposure is bad. On the contrary, if substantial exposure is substandard and some loans are bad, the borrower can be deemed defaulted even if some banks have not yet acknowledged the deterioration of their own exposure. Clearly, if a client is borrowing from one bank its status depends only on the quality of the exposure to that bank. The CR defines three statuses: performing, nonperforming or defaulted ("in sofferenza" in Italian).

A key advantage of using the CR data is that we can study a very large sample of small and medium enterprises, while the literature typically analyses insolvency using data on bond defaults. In Italy bank debt accounts for almost two thirds of firms' financial debt and only very large firms resort to bond issuances (Bank of Italy 2014). Therefore, our analysis is relevant for assessing the determinants of default for a substantial share of the economy.

Furthermore, this notion of default is more general than bankruptcy because the opening of a formal bankruptcy procedure is a sufficient but not necessary condition for entering the CR default status. Given the length and costs of judiciary procedures, banks often resort to debt restructuring or out-of-court settlements.

We construct our sample from the cross-section of firms with balance sheet and financial debt information in 2007-2008 that are also in the CR; we drop those that are defaulted already in 2008. This matched sample consists of about 200,000 firms. We follow them over time until the end of 2012 and define as defaulting those that switch status within the period. On an annual basis, the flow of firms that default steadily increased, from $2.8 \%$ in 2009 to 4.9 in 2012 (Table 1), consistently with the aggregate series plotted in Fig. 2. The incidence of defaults is higher in the construction sector.

We divide the firms into two subsamples: those that default (D) and those that do not (ND). Firms that become nonperforming (substandard, restructured or past-due) but do not default by 2012 are kept among the ND, since they could still revert to performing status, although it is unlikely. As discussed below, aggregating them with the $\mathrm{D}$ firms does not change the results of the analysis.

Figure 3 shows the yearly growth rate of aggregate sales of the two types of companies between 2003 and 2008. Until 2007 their sales behaved in a very similar way. In 2008, when the Italian economy entered the recession, sales growth started to diverge, reflecting the differentiated impact of the exogenous macroeconomic shock across firms.

Figure 4 shows the aggregate value of leverage for the two types of firms. Type D firms had a much higher leverage ratio (financial debt divided by the sum of financial debt and equity) than ND ones, well before 2008. Until 2007 leverage was increasing for both categories, at a similar pace. For D firms it went from 72 to $77 \%$ between 
Table 1 Sample description: firms defaulting and non defaulting between 2009 and 2012, by year and industry

\begin{tabular}{|c|c|c|c|c|}
\hline & 2009 & 2010 & 2011 & 2012 \\
\hline \multicolumn{5}{|l|}{ Manufacturing } \\
\hline Number of newly defaulted firms in the year (a) (1) & 1949 & 2141 & 1813 & 2123 \\
\hline Number of firms not defaulted (b) (2) & 57,414 & 55,007 & 52,260 & 47,819 \\
\hline Of which: performing firms (3) & 48,490 & 48,177 & 47,282 & 45,010 \\
\hline Default rate $(a) /(a+b)$ & 3.3 & 3.7 & 3.4 & 4.3 \\
\hline \multicolumn{5}{|l|}{ Services } \\
\hline Number of newly defaulted firms in the year (a) (1) & 2533 & 3210 & 3238 & 3687 \\
\hline Number of firms not defaulted (b) (2) & 97,297 & 92,500 & 86,888 & 76,552 \\
\hline Of which: performing firms (3) & 81,577 & 80,496 & 78,349 & 71,796 \\
\hline Default rate $(a) /(a+b)$ & 2.5 & 3.4 & 3.6 & 4.6 \\
\hline \multicolumn{5}{|l|}{ Construction } \\
\hline Number of newly defaulted firms in the year (a) (1) & 1145 & 1499 & 1700 & 2016 \\
\hline Number of firms not defaulted (b) (2) & 35,069 & 32,402 & 29,540 & 24,576 \\
\hline Of which: performing firms (3) & 26,535 & 25,764 & 24,767 & 22,006 \\
\hline Default rate $(a) /(a+b)$ & 3.2 & 4.4 & 5.4 & 7.6 \\
\hline \multicolumn{5}{|l|}{ Total (4) } \\
\hline Number of newly defaulted firms in the year (a) (1) & 5730 & 7005 & 6910 & 7987 \\
\hline Number of firms not defaulted (b) (2) & 196,395 & 186,281 & 174,763 & 154,415 \\
\hline Of which: performing firms (3) & 162,158 & 159,935 & 155,793 & 143,841 \\
\hline Default rate $(a) /(a+b)$ & 2.8 & 3.6 & 3.8 & 4.9 \\
\hline
\end{tabular}

Note Default rates are percentages. Data are from Cerved Group and Central Credit Register. Limited Liability companies and corporations that report information on financial debt. The data reported are weighted averages for the firms that have data in each year

(1) Firms that default in the period 2009-2012 based on the records in the Credit Register (a client is defaulted if net bad loans are greater than $10 \%$ of total outstanding loans provided by all banks and reporting financial companies). (2) Firms that are never recorded as defaulted in the period 2009-2012 by the Credit Register and have balance sheet information in the given year; firms can have past-due, restructured or substandard loans. (3) Firms that are always performing in years 2009-2012 and have balance sheet information in the given year. (4) Total includes also agriculture, extraction and energy

2003 and 2007; for ND firms it increased from 52 to almost $56 \%$. In 2008 leverage kept increasing for $\mathrm{D}$ firms while it declined for the others.

In Table 2 we report the incidence of defaults breaking the sample into the quartiles of 2008 leverage and average sales growth during 2009-2012. Sales growth is the mean of the two most recent observations available for each firm.

More than half of the firms reported negative sales growth, as the median of the distribution is $-1.4 \%$. The worst performing quartile of firms had a contraction in sales of at least $13.9 \%$ on an annual basis. The best quartile had positive growth, greater than or equal to $9.7 \%$. As shown in Fig. 5a, the default rate is more than quadruple for firms in the bottom quartile of sales growth $(8 \%)$ with respect to the other companies $(1.7 \%)$. It also increases monotonically with initial leverage. The joint distribution of leverage and change in sales is shown in Fig. 5b. Among firms 


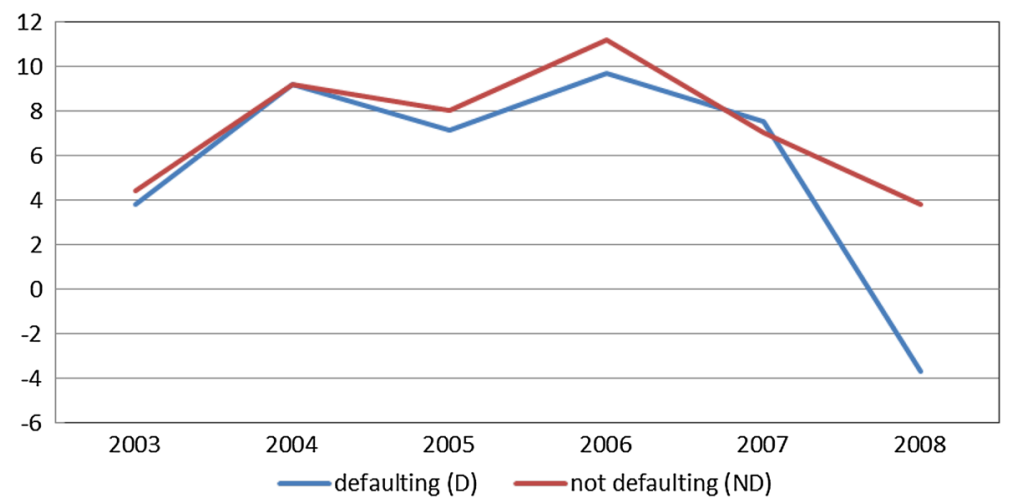

Fig. 3 Yearly growth rate of sales by default status 2009-2012. Note Percentage changes. Data are from Cerved Group and Central credit register (CR). The sample includes nonfinancial companies for which data on financial debts are available in each year and have loans in the CR. For the definitions see the ESM Data Appendix

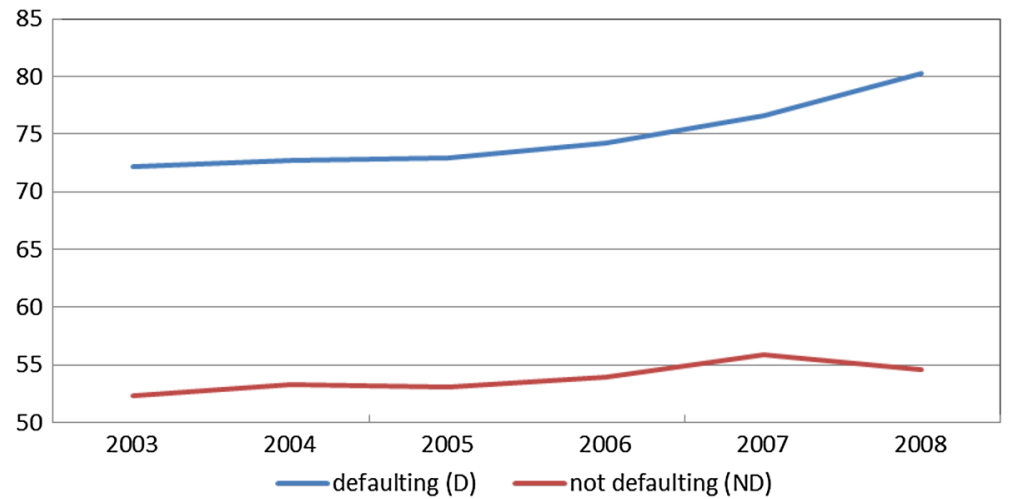

Fig. 4 Firm Leverage by default status in 2009-2012. Note Percentage values. Data are from Cerved Group and Central credit Register. The sample includes nonfinancial companies for which data on financial debts are available in each year and have loans in CR. Leverage is financial debt divided by the sum of financial debt and equity. For the definition of default see the ESM Data Appendix

with the highest drop in sales, those in the bottom quartile of leverage (less than $47 \%$ ) have an average default rate of $3.8 \%$, about a third of the $10.8 \%$ rate of firms in the top quartile (leverage greater than $90 \%$; see also Table 2).

Table 3 reports descriptive statistics for a number of economic and financial variables for the D and ND firms. We recall that balance sheet data are usually unavailable for firms once they default so as firms become insolvent they tend to exit the sample. Overall, the firms in our sample are small by international standards. Median total assets are similar in the two subsamples while mean total assets of the D firms are almost half (5.2 million euros) than those of the ND firms (10.3 million). The reason of this discrepancy is that the size distribution of the D firms is skewed, with a small number of very large corporations that have very low default rates. 
Table 2 Frequency of default by year, leverage and change in sales

\begin{tabular}{|c|c|c|c|c|c|}
\hline Variables & 2009 & 2010 & 2011 & 2012 & Mean \\
\hline \multicolumn{6}{|l|}{ By 2008 leverage (1) } \\
\hline Firms with leverage in quartile $1(\leq 46.7 \%)$ & 0.7 & 1.2 & 1.3 & 2.1 & 1.3 \\
\hline Firms with leverage in quartile $2(>46.7$ and $\leq 73.8 \%)$ & 1.2 & 2.1 & 2.5 & 3.5 & 2.3 \\
\hline Firms with leverage in quartile 3 ( $>73.8$ and $\leq 89.7 \%$ ) & 2.1 & 3.5 & 4.1 & 5.7 & 3.8 \\
\hline Firms with leverage in quartile 4 (> $89.7 \%)$ & 3.1 & 4.8 & 5.5 & 7.6 & 5.3 \\
\hline \multicolumn{6}{|l|}{ By change in sales 2009-2012 (2) } \\
\hline Sales change quartile 1 (yearly mean $\leq-13.9 \%$ ) & 4.6 & 7.0 & 8.5 & 11.7 & 8.0 \\
\hline Sales change quartile $2,3,4$ (yearly mean $>-13.9 \%$ ) & 0.8 & 1.6 & 1.8 & 2.7 & 1.7 \\
\hline \multicolumn{6}{|l|}{ By leverage and change in sales } \\
\hline \multicolumn{6}{|l|}{ Sales change quartile 1 (yearly mean $\leq-13.9 \%$ ) } \\
\hline Leverage in quartile $1(\leq 46.7 \%)$ & 2.1 & 3.3 & 4.0 & 6.0 & 3.8 \\
\hline Leverage in quartile $2(>46.7$ and $\leq 73.8 \%)$ & 3.1 & 5.6 & 7.1 & 10.1 & 6.5 \\
\hline Leverage in quartile $3(>73.8$ and $\leq 89.7 \%$ ) & 5.1 & 8.1 & 10.4 & 14.2 & 9.5 \\
\hline Leverage in quartile $4(>89.7 \%)$ & 6.8 & 9.7 & 11.2 & 15.5 & 10.8 \\
\hline \multicolumn{6}{|l|}{ Sales change quartile $2,3,4$ (yearly mean $>-13.9 \%$ ) } \\
\hline Leverage in quartile $1(\leq 46.7 \%)$ & 0.3 & 0.7 & 0.8 & 1.3 & 0.8 \\
\hline Leverage in quartile $2(>46.7$ and $\leq 73.8 \%)$ & 0.6 & 1.2 & 1.4 & 1.9 & 1.2 \\
\hline Leverage in quartile 3 (>73.8 and $\leq 89.7 \%$ ) & 1.0 & 2.0 & 2.2 & 3.3 & 2.1 \\
\hline Leverage in quartile $4(>89.7 \%)$ & 1.5 & 2.9 & 3.4 & 5.0 & 3.2 \\
\hline
\end{tabular}

Data are from Cerved Group and Central Credit Register. Limited Liability companies and corporations that report information on financial debt and are reported in the Credit register with outstanding loans, used or unused. Values are percentages

(1) Financial debt/(financial debt + equity), 2007 or 2008. (2) Mean of the most recent two yearly changes in sales available in the period 2009-2012

A Marginal distributions

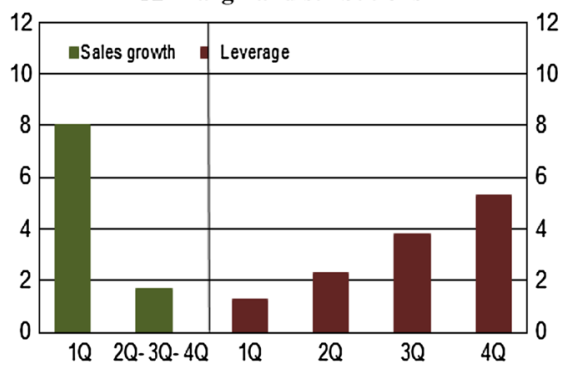

B Joint distribution

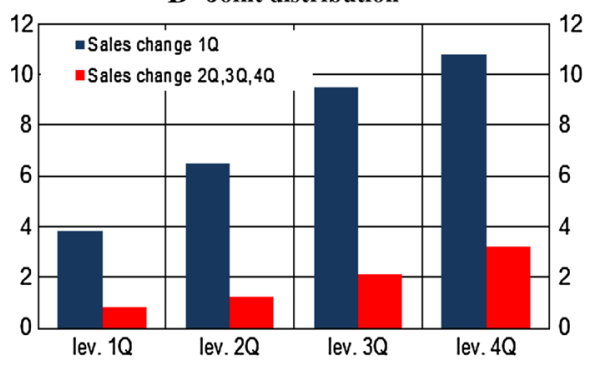

Fig. 5 Share of newly defaulting firms, by leverage (2008) and change in sales (2009-2012). Note Percentage changes. The default rates are averages of the yearly default rates over the period 2009-2012. Data from Cerved Group and Central Credit Register, with data in the Register for 2008. For the definition of default see the ESM Data Appendix. The sample includes nonfinancial companies for which data on financial debts are available in each year. Leverage is financial debt divided by the sum of financial debt and equity and is computed in 2008 or 2007 based on availability of data. The distribution of sales growth is based on the mean of the last two yearly changes in sales between 2008 and 2012 


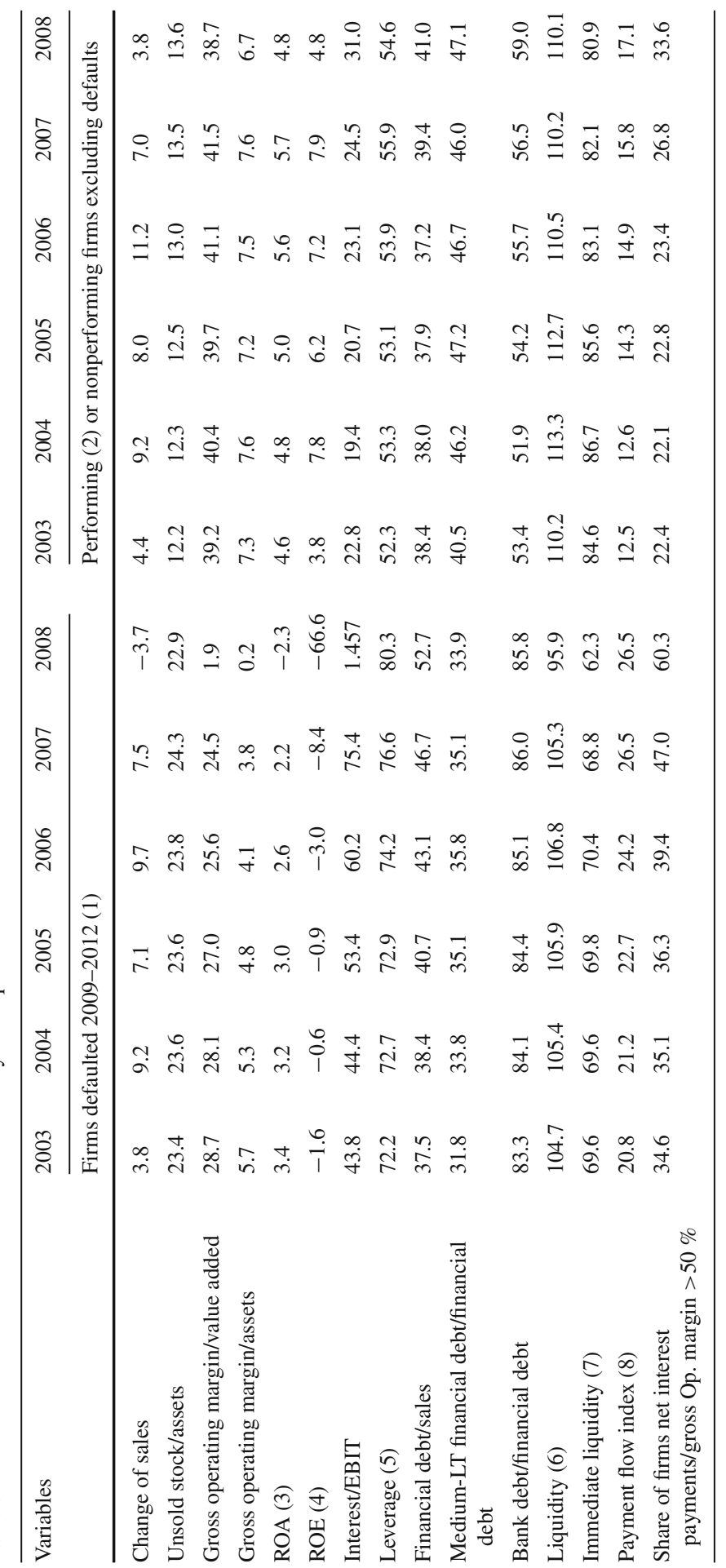




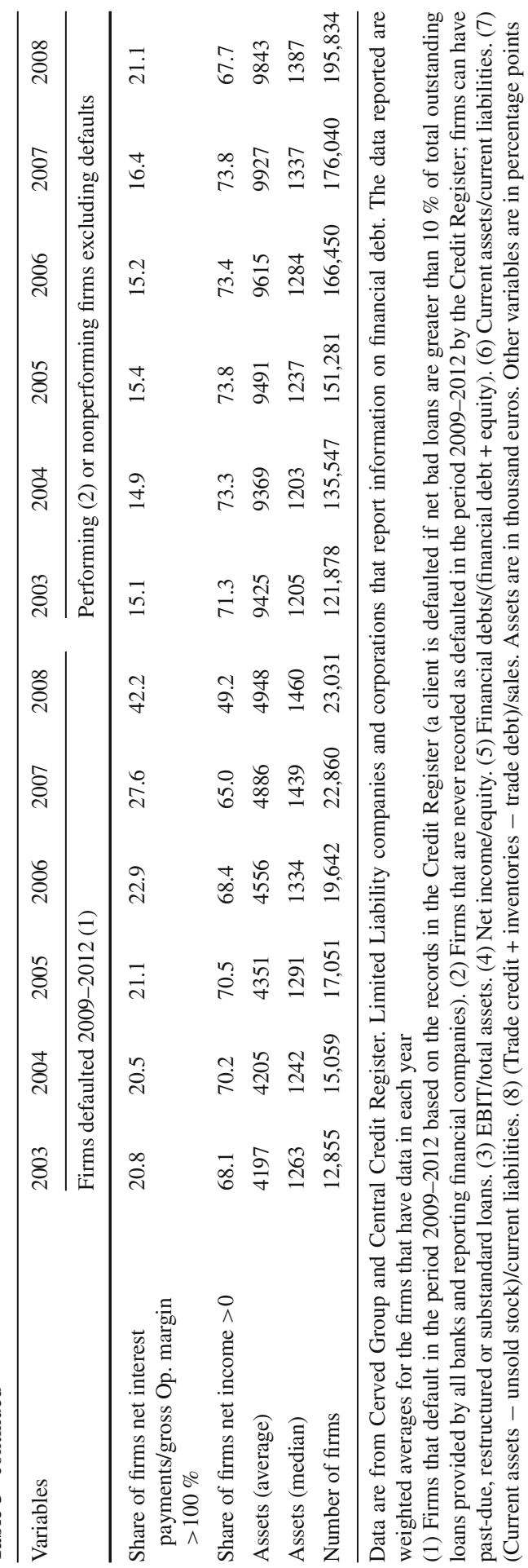


The statistics in Table 3 show that the D firms have lower productivity (measured by the Gross Operating Margin/Value Added or the Gross Operating Margin/Assets) and are much less profitable than the ND firms in 2003-2007 (ROA and ROE). These differences are stable over the sampled years, and to some extent reflect structural differences across sectors. The weighted average for ROE is negative for the D firms, positive for the ND firms.

The negative aggregate figure for the $\mathrm{D}$ firms is the result of a small number of large firms having substantial losses and a large number of firms with positive but weak profitability. The percentage of firms that have positive net income is lower (between 60 and $70 \%$ ) among the D firms than the ND firms (above $70 \%$ ). In both groups this share drops in 2008, the first year of recession, but the extent of the change is larger for the D firms than for the ND ones.

The data on the financial structure of the two types of companies reveal substantial differences in addition to the wide differential in leverage shown in Fig. 4. While the ratio of financial debt to sales is very similar, the D firms resort to a larger extent to bank debt than the ND firms; they also have a greater share of short term debt and are less liquid.

The key differences remain even when repeating the analysis by sector (manufacturing, services, construction, other).

\section{Empirical Model and Variables}

We specify a reduced form logit model of the probability of default as a function of financial and demographic variables. Since the logit model is widely used in the literature (see Altman and Sabato 2007) we do not motivate this choice for the sake of brevity. Given the limited number of years, we study occurrences of default by 2012 , i.e. we consider the probability that a firm defaults at any point in time between 2009 and 2012. The dependent variable is equal to 1 if the firm switches to default status (DEFAULT), 0 otherwise.

The key variable under investigation is leverage, defined as financial debt divided by the sum of financial debt and equity (LEVERAGE). In the absence of financial frictions leverage should not affect firm performance and the probability of default if the productivity and operating efficiency of the firm are fully accounted for.

If there are capital market imperfections, firms that are economically viable might end up defaulting because they cannot obtain the funds required to continue their operations or to invest in the aftermath of a negative demand shock. ${ }^{2}$

One potential concern is spurious correlation generated by unobservable characteristics affecting both leverage and default. The most obvious candidate is performance. Less productive firms might end up having high leverage and higher probability of default. We address this problem in two ways. The first is to include a number of control variables that capture firm characteristics, particularly the operating performance

\footnotetext{
2 Our notion of default refers to financial distress, which is different from economic distress; if there were perfect capital markets a viable but illiquid firm would be able to obtain financing. Empirically, it is difficult to distinguish financial from economic distress.
} 
of the firm. Second, we look for evidence of the mechanism by which leverage should increase default, as discussed in Sect. 5 below.

The hypothesis we test is that the probability of defaulting between 2008 and 2012 is a function not only of variables capturing the performance of the firm, but also its financial structure:

$$
\operatorname{Pr}(\text { DEFAULT })_{i t}=f\left(X_{i t}, \text { LEVERAGE }_{i t-1}\right)+e_{i t}
$$

As shown in Eq. (1), LEVERAGE affects default through a separate channel with respect to the other variables (vector $\mathrm{X}$ ) that capture the performance of the firm. We assume that these characteristics are persistent in the sense that the cross-sectional variation across firms is well captured by the initial distribution so $\mathrm{X}_{\mathrm{it}}$ is measured at the beginning of the period, with the exception of our measure of the shock faced by firms during the economic contraction. Using predetermined variables limits the potential that LEVERAGE might affect variables in the $\mathrm{X}_{\mathrm{it}}$.

The variables that we include in our main specification are measures of liquidity and profitability as they are shown to affect default in the literature (e.g. Altman 1968; Carling et al. 2007), as well as demographic characteristics. Profitability is defined as OPPROFIT/TA (Gross Operating Profit/Total Assets). We choose a measure of operating profits because it is best suited to capture productivity and is not influenced by interest payments.

We include a measure of liquidity, given by Current Assets/Current Liabilities (LIQUIDITY) because firms with more cash and liquid assets can draw down their liquidity holdings to absorb the impact of a temporary adverse profitability shock on earnings.

We control for the share of bank debt (Bank Debt/Financial Debt) because for a large number of firms financial debt includes loans from shareholders. Shareholders tend to provide some capital in the form of loans rather than through equity because of tax incentives. We do not expect these loans to play the same role as outside debt in affecting the probability of default.

We also include the log of total assets (LOGASSETS) and its square to control for size, a set of dummy variables for industries, dummies for the region in which the firm has its headquarters (North-West, North East, Center, South), and the age of the firm in 2008 .

The level of operating profitability might not be enough to capture the prospects of the firm. A firm might be already losing market share and facing problems before the recession. This could be reflected in high leverage due to lack of income generating capacity and a higher probability of default in the future. We included a measure of the average yearly change in sales before the crisis (SALESDROP 2006-2008) to control for the dynamics of performance. A firm with deteriorating performance might have high debt, as we discussed before.

Some studies found that macroeconomic conditions improve significantly the predictive power of statistical default models (e.g. Carling et al. 2007). Since we focus on a cross-section we cannot include macroeconomic variables that are common to all firms. Instead, we include a measure of the firm specific shock that firms faced during the recession. We use the change in sales between 2009 and 2012, computed 
as the average of annual changes over the years for which the information is available (SALESDROP 2009-2012). To facilitate the interpretation of coefficients we use the transformation $(-1) \times($ change in sales) in the regressions. The effect on the default probability should therefore be positive.

The purpose of including the change in sales in our regression is not only to improve the accuracy of our model but also to assess the role of leverage, controlling for differences across firms in the shock they face. The intuition is that the main channel through which the recession affected firms was a drop in demand, both domestic and foreign, and that firms were affected differently depending on the composition of their clients, an unobserved factor. We prefer the change in sales to the change in profits because the former is not influenced by the financial structure and the financing conditions of firms.

Data on the change in sales during the crisis are available only for a smaller sample of firms, about 105,000. Descriptive statistics for this sample are reported in Table 4. The mean growth rate of sales was $7 \%$ in 2006-2008 and -5\% during 2009-2012. The average leverage is $60 \%$; $83 \%$ of financial debt is bank debt.

We compared means for the larger dataset (Full sample) and the estimation sample to assess possible differences due to selection (ESM Table a5). The geographic and industry distribution is similar but the firms in the estimation sample are larger, have a lower leverage (60 versus $65 \%$ ) and are more profitable. Nevertheless, they are not stronger along all dimensions since they are less liquid and have a higher share of bank debt. Overall, the firms in the subsample have a lower default frequency, 6.1 versus $10.6 \%$ in the larger dataset, suggesting that most of the selection depends on missing balance sheet data due to insolvency. Some robustness tests will be discussed in Sect. 5 below.

\section{Results}

Table 5 reports the results of the first set of regressions. We show marginal effects computed as averages of predicted marginal effects from the model. We study the contribution of each financial variable by estimating separate regressions with the set of demographic controls (size, region, age and industry dummies) and one balance sheet variable at a time. In the last specification of the table we include them all.

The results show that leverage has a positive, monotonically increasing effect on the probability of default (column B) as expected; the coefficient of the dummy of the top quartile of leverage (greater than $84.3 \%$ ) indicates that, ceteris paribus, the estimated default probability is about $10 \%$ points higher than the one of firms in the bottom quartile (less than $38.8 \%$ ), the excluded category.

The coefficient of the pre-crisis drop in sales is statistically significant and has the expected positive sign, but the economic effect is not very large. Firms in the bottom quartile of sales (yearly sales drop greater than $4 \%$ ) have a $3.5 \%$ higher probability of default with respect to those in the top quartile (yearly sales growth above $14 \%$ ). The effect is not monotonic.

The other financial covariates are statistically significant at the standard levels and have the expected signs. The probability of default declines as operating profitability 


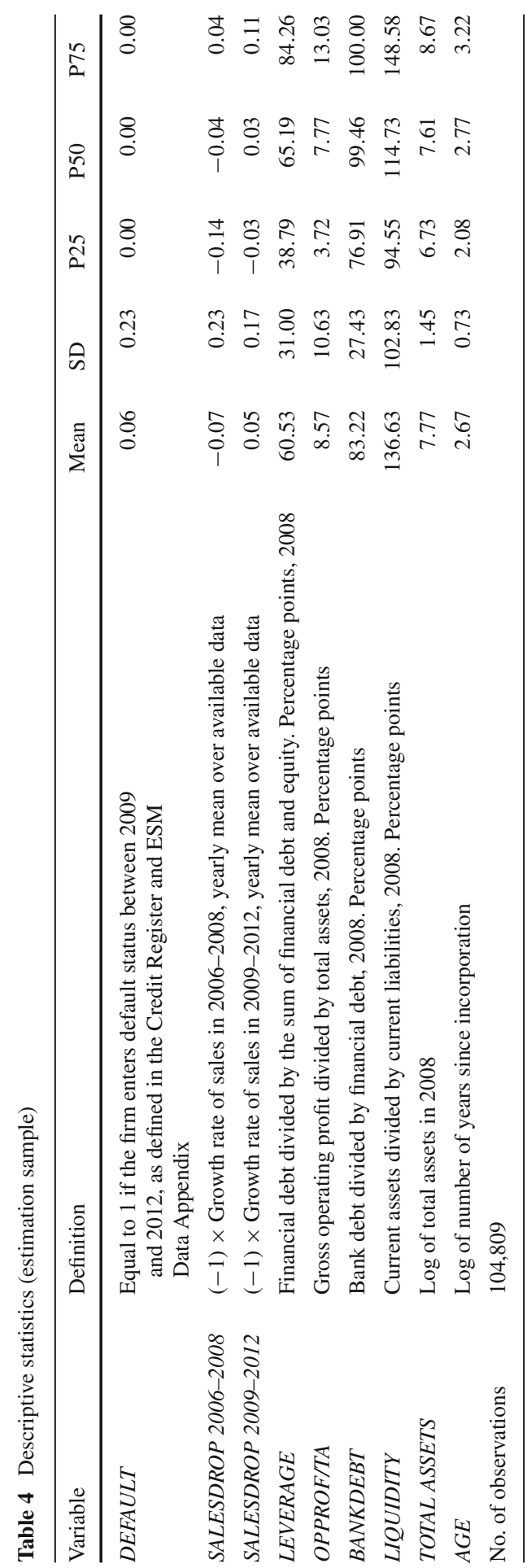




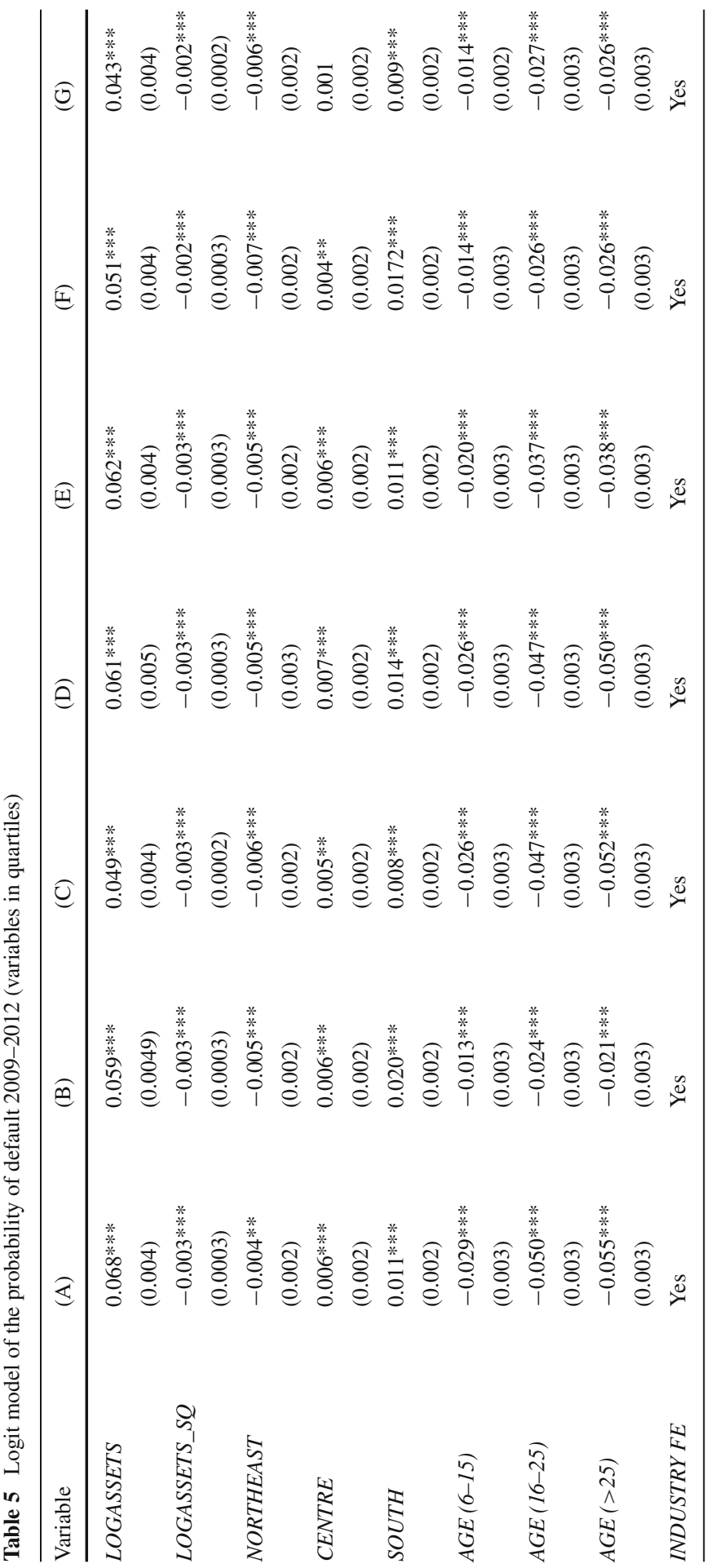




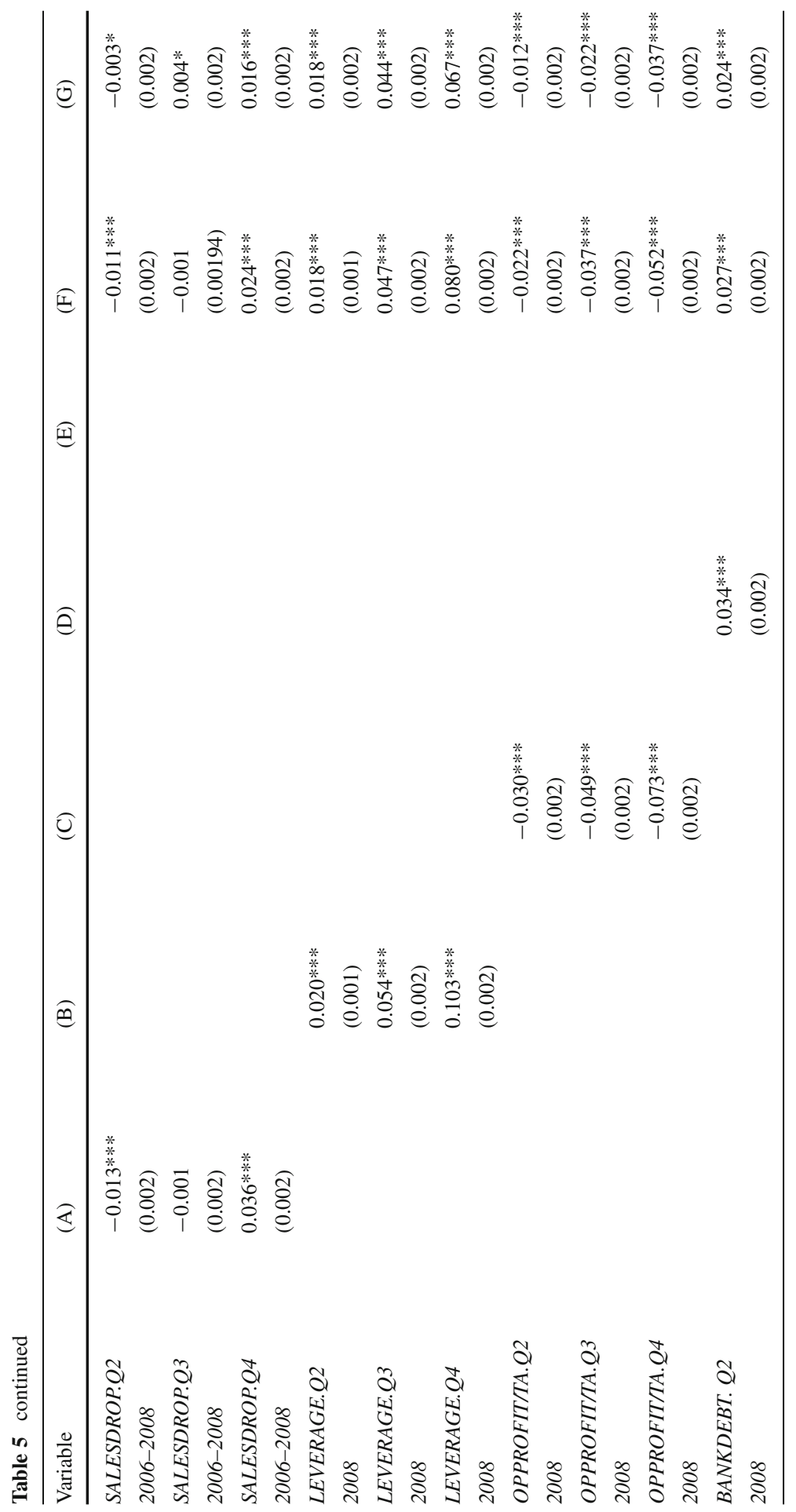




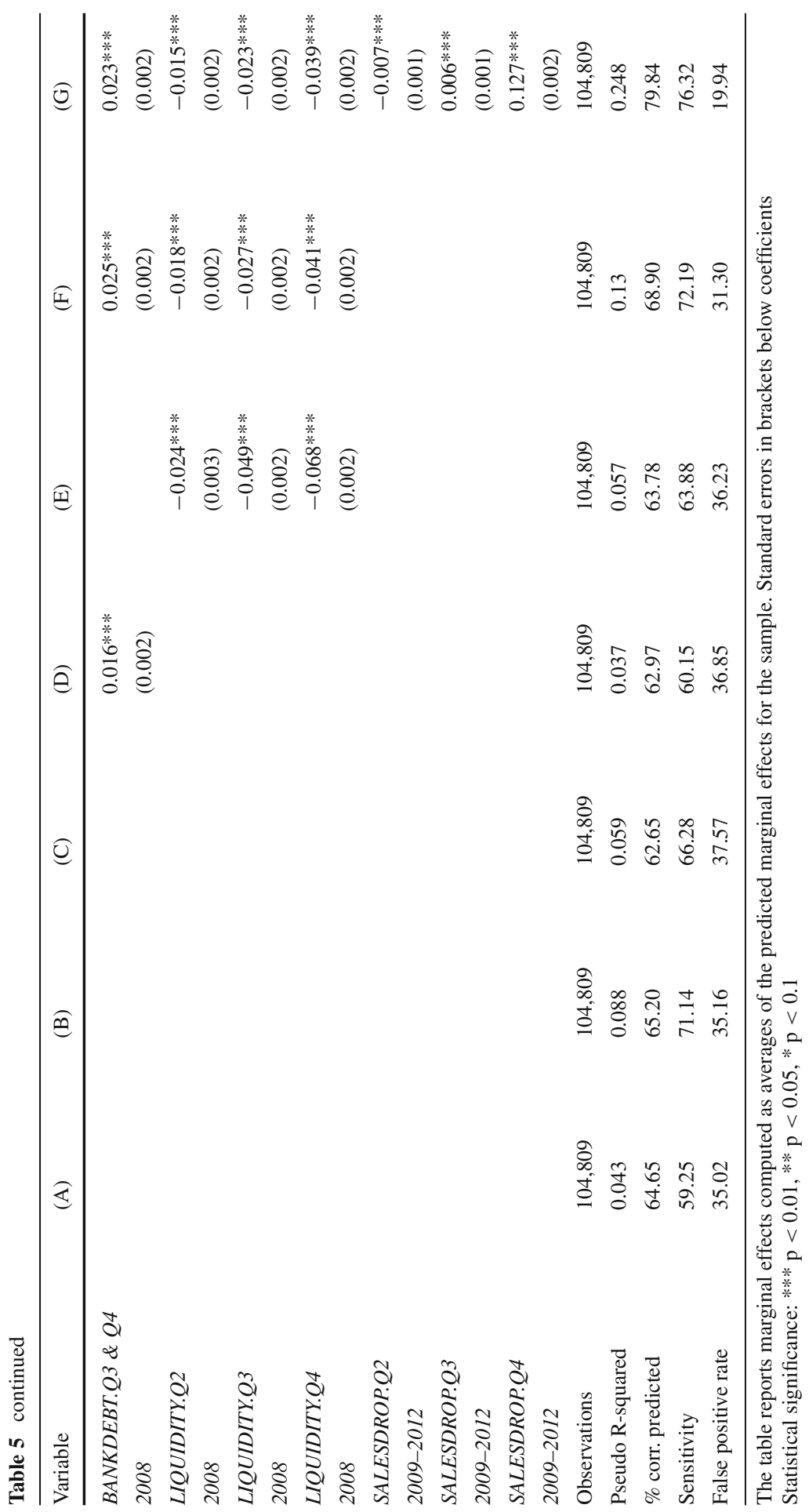


and liquidity go up. It is higher when firms have a substantial share of bank debt, as expected, but there is not much difference in the coefficients as the share of bank debt increases above the median (in the tables we collapsed the 3rd and 4th quartiles for the sake of brevity). We also find that firm age is significant and has a negative coefficient indicating that younger firms tend to be riskier, consistent with the evidence in the literature.

So far we related the probability of default to variables that were pre-determined with respect to the shock that hit the firms during the recession. Although firm size, industry and region account for some of the heterogeneity in the impact that the recessions had on firms, the yearly change in sales 2009-2012 should improve the fit of the model because it is a firm-specific shock. The implicit assumption is that the change in sales is not the result of an anticipated increase in the probability of default by clients.

Not surprisingly, the estimated coefficient of the full model (column G) shows that the drop in sales during the recession is much more relevant in terms of both explanatory power and economic significance than the change of sales in the three years before the recession. The Pseudo R squared almost doubles when we include this variable.

The improvement in the explanatory power of the model due to the addition of SALESDROP 2009-2012 is shown also by the changes in the following accuracy indicators, reported in the last rows of the table: the share of correctly predicted (the share of firms that are classified correctly, defaulted or not defaulted ${ }^{3}$ ); the sensitivity rate (the share of defaulting firms that are correctly classified); the false positive rate (the share of ND firms that erroneously predicted as D by the model). In particular, the percent of correctly predicted cases jumps from 69 to $80 \%$; the sensitivity rate increases from 72 to $76 \%$, and the false positive rate declines from 31 to $20 \%$.

We note that adding SALESDROP 2009-2012 does not change the economic and statistical significance of leverage in explaining default. The difference in the default probability between firms in the top quartile of leverage and those in the bottom one is about $7 \%$ points, almost the same as the one estimated without controlling for the contemporaneous change in sales. The two variables have independent effects on the probability of insolvency.

We then estimate the model using continuous variables rather than quartiles of leverage and sales (Table 6). All the results hold. The coefficient of leverage indicates that increasing leverage by $10 \%$ points (around one third of the standard deviation) the probability of default increases by $0.7 \%$ points, a sizable effect since the frequency of default in the sample is about $6 \%$. The coefficient of the drop in sales before the crisis is significant and positive but the economic effect is small: a $10 \%$ point drop in sales before the crisis (the average change of sales in 2006-2008 is almost $7 \%$ for our sample) raises only modestly the probability of default in subse-

\footnotetext{
3 The sensitivity rate, the false positive rate and the share of correctly predicted depend on the value of the threshold that is used to get the predicted values. We opted for a conservative choice of the threshold, approximated by the sample frequency of positives (see Hoetker 2004). The use of alternative thresholds does not change the ranking of the models in terms of accuracy.
} 


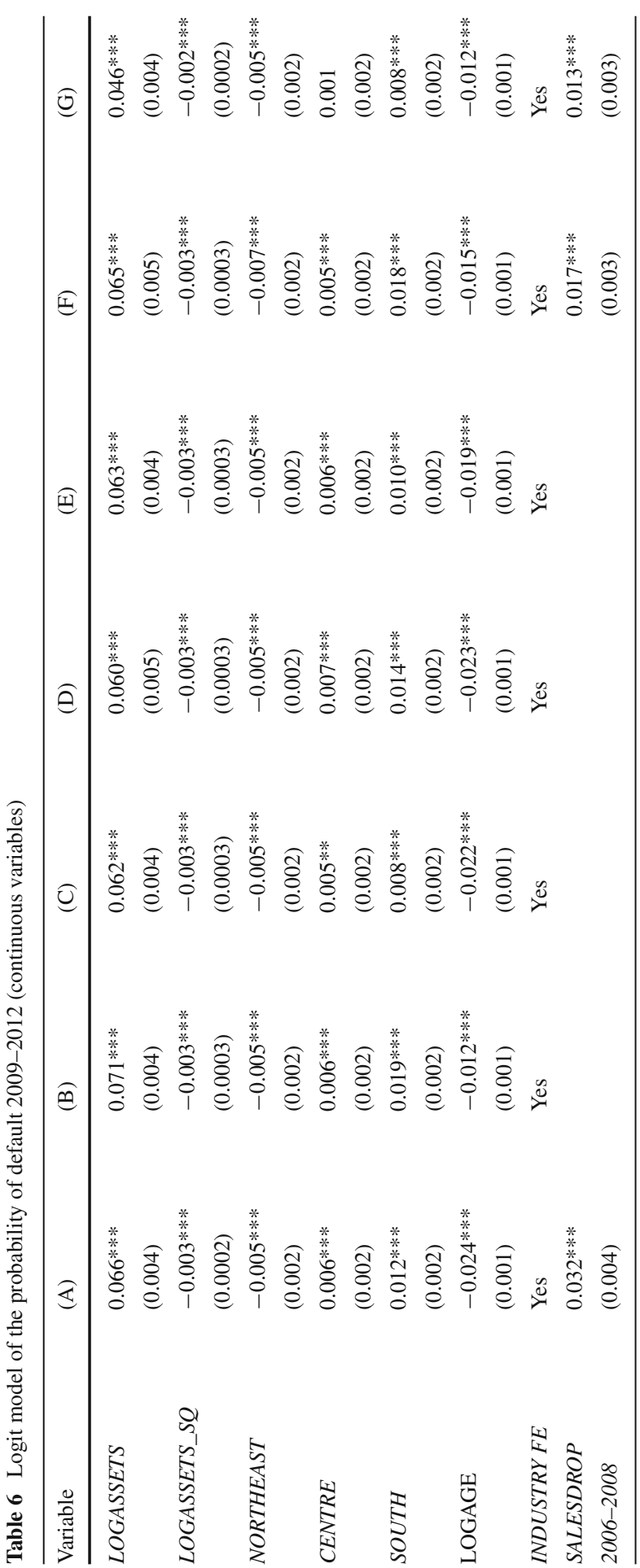




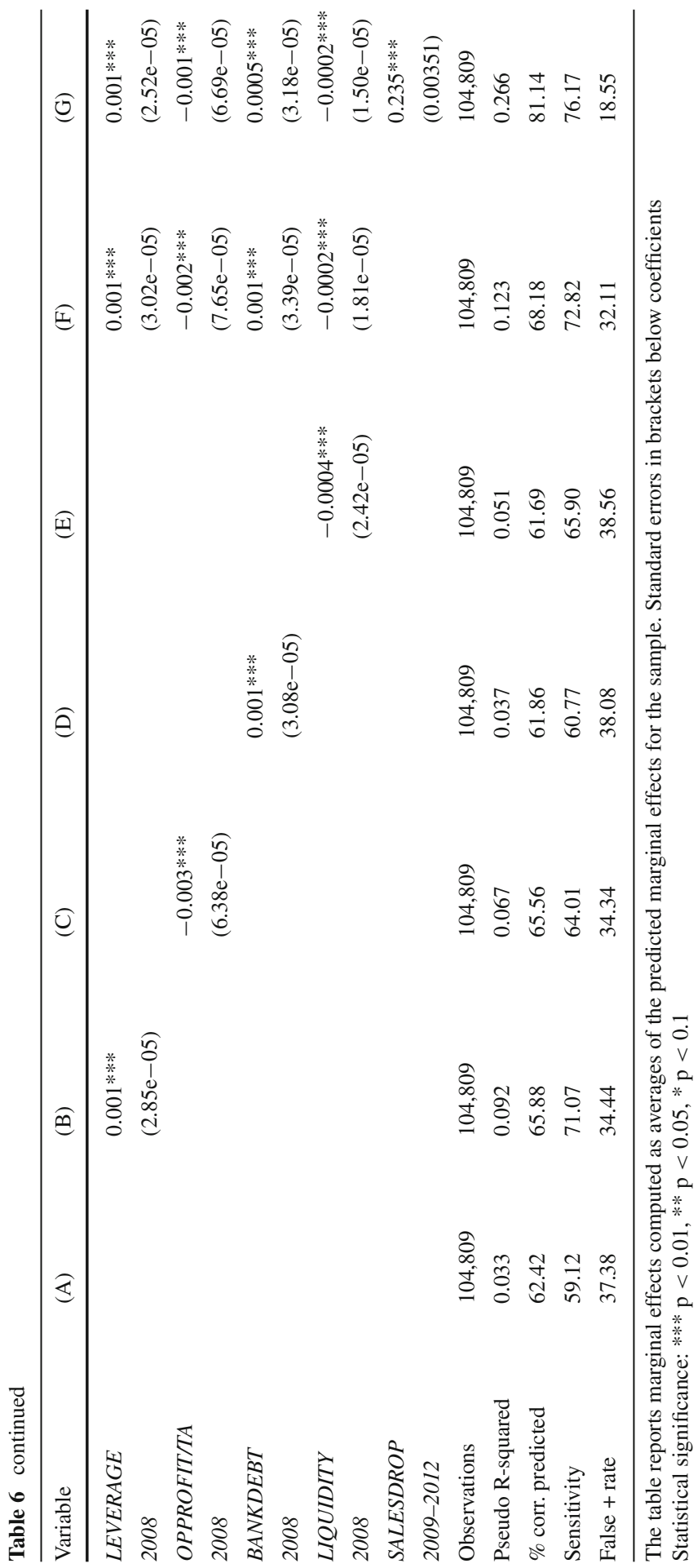


quent years $(0.1 \%$ points $)$. As in the previous model, adding the drop in sales during the crisis among the set of covariate improves the explanatory power of the model (column G, Table 6) and does not change the order of magnitude of the effect of leverage.

\subsection{Interaction Between Sales Drop and Leverage}

In this paragraph we explore the role of initial leverage in the transmission of the shock to sales by adding interaction terms between SALESDROP 2009-2012 and LEVERAGE. To facilitate the interpretation of coefficients we use a specification with dummy variables for each quartile of leverage and estimate a linear probability model (LPM) instead of the logit model.

The results are reported in Table 7 . The first column shows the linear model with the full set of controls without the interaction terms. The marginal effects are very similar to those obtained with the logit model, reported in the last column. In columns (B)-(E) the model is estimated on subsamples of firms in the quartiles of leverage. In column (F) we interact the leverage quartile dummies with the drop in sales during the crisis. The coefficients of all the interaction terms are statistically significant and monotonically increasing. An additional drop by $10 \%$ points in yearly sales $2009-$ 2012 increases the probability of default by about $6 \%$ points for the firms whose leverage falls in the top quartile; the same shock to sales, on the other hand, yields an estimated increase in the default probability by less than $2 \%$ points for the firms whose leverage falls in the bottom quartile.

\subsection{Robustness}

We performed some robustness checks of our main results. We changed the specification to avoid the selection of firms due to the lack of data on sales between 2003 and 2007. Removing the variable SALESDROP 2006-2008 and other financial and economic covariates increases the sample size to around 150,000 firms. The results on our main identification variables-leverage and drop in sales during 2009-2012reported in Table 8 (columns $(\mathrm{A})-(\mathrm{C})$ ), are unchanged.

In a second check we calculated the change in sales over the period 2005-2007 instead of 2006-2008 since the economy entered the recession in the last quarter of 2008. The estimates (Table 8, columns (D)-(F)) show that there are no substantial changes in the coefficients of interest. In an additional robustness test we estimated our model on the level of leverage in 2007 rather than that of 2008; the estimates (not reported) confirm our previous findings.

Finally, we estimated the LPM model employing a wider definition of nonperforming borrower that includes not only default but also situations in which the firm has a significant amount of past-due, restructured or substandard loans. Indeed, given the truncation of the data in 2012, we could be underestimating defaults because almost 17,000 firms exhibit repayment difficulties by 2012 but are not recorded as defaulted yet. The estimates, reported in Table 9, confirm our previous findings both in terms of significance and magnitude of the coefficients. 


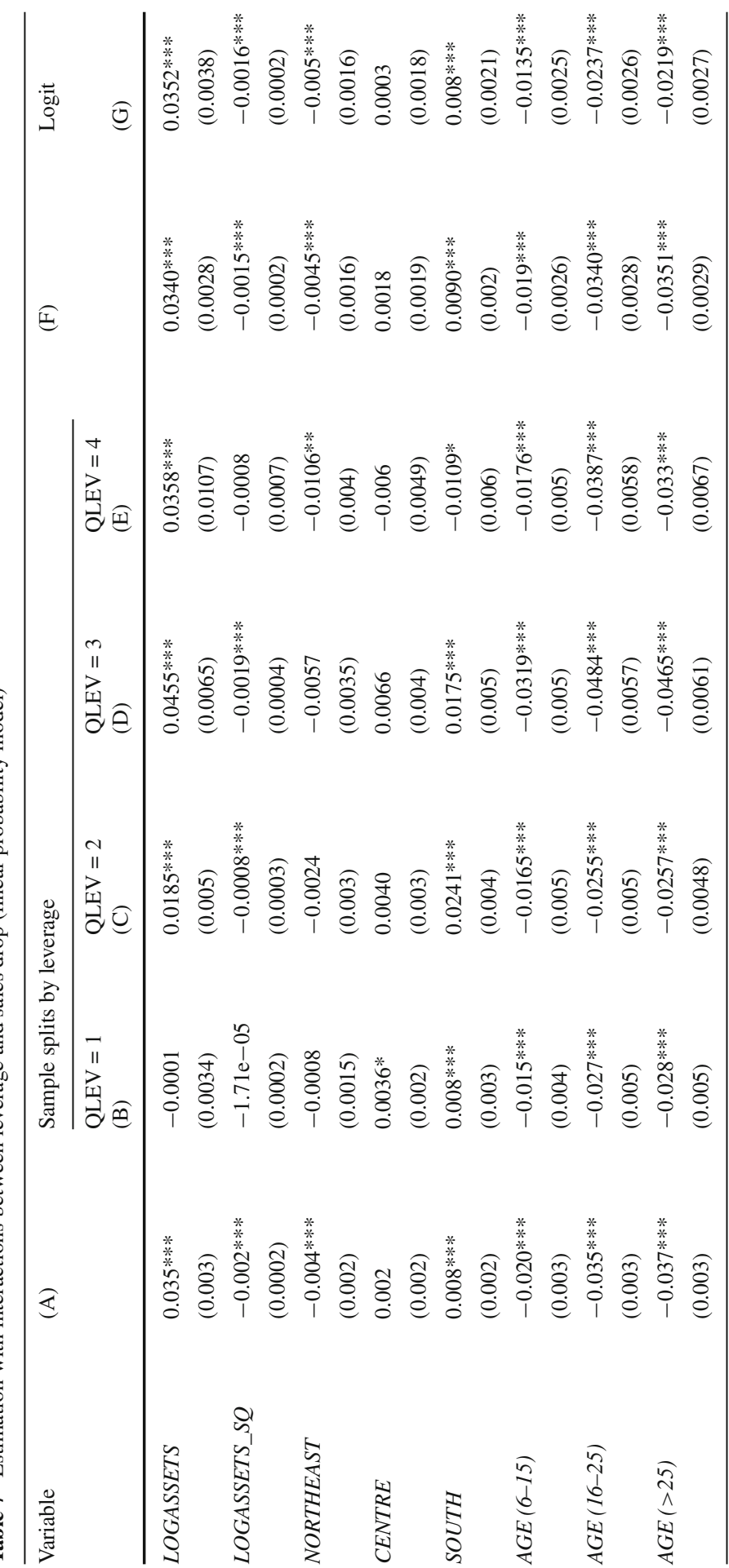




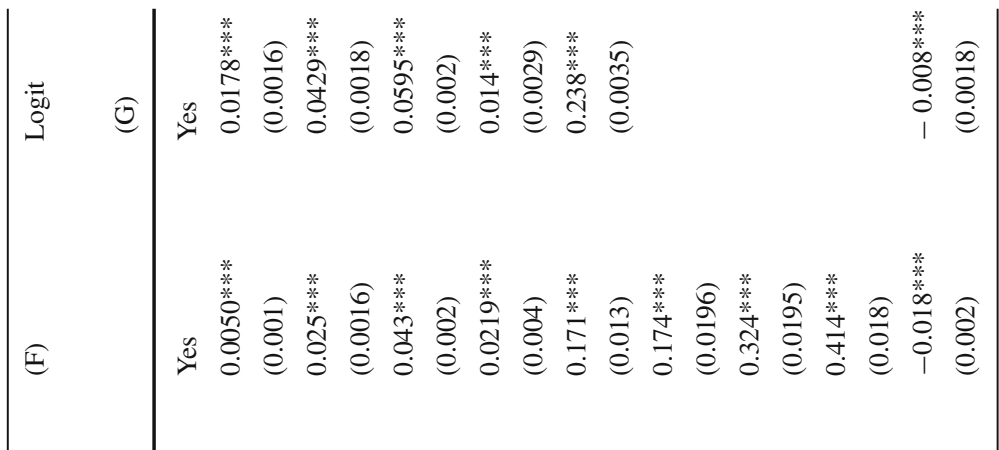

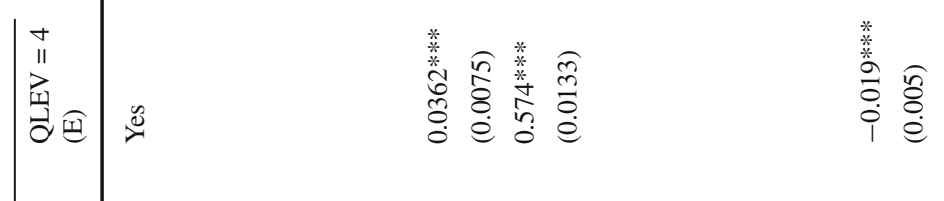

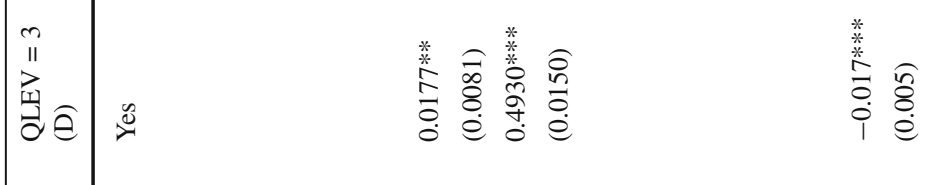

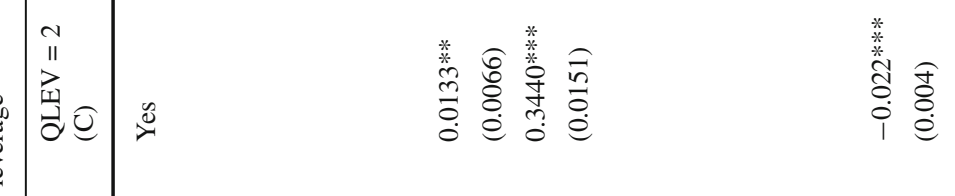

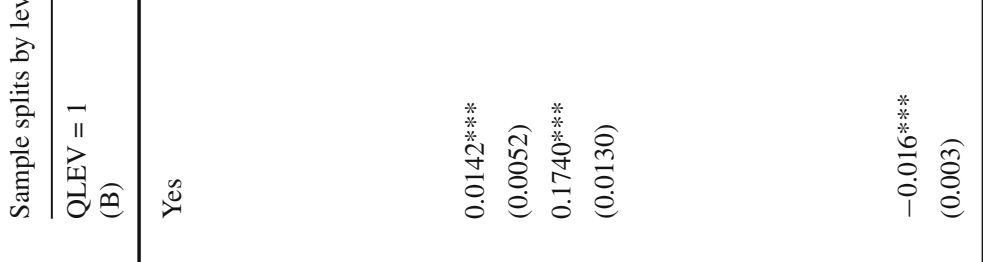

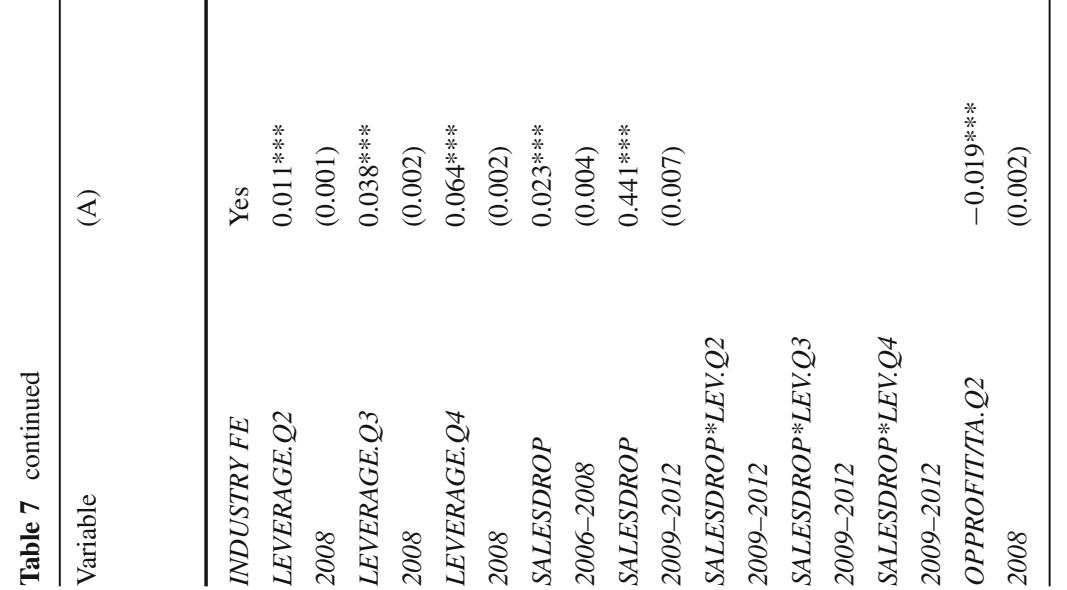




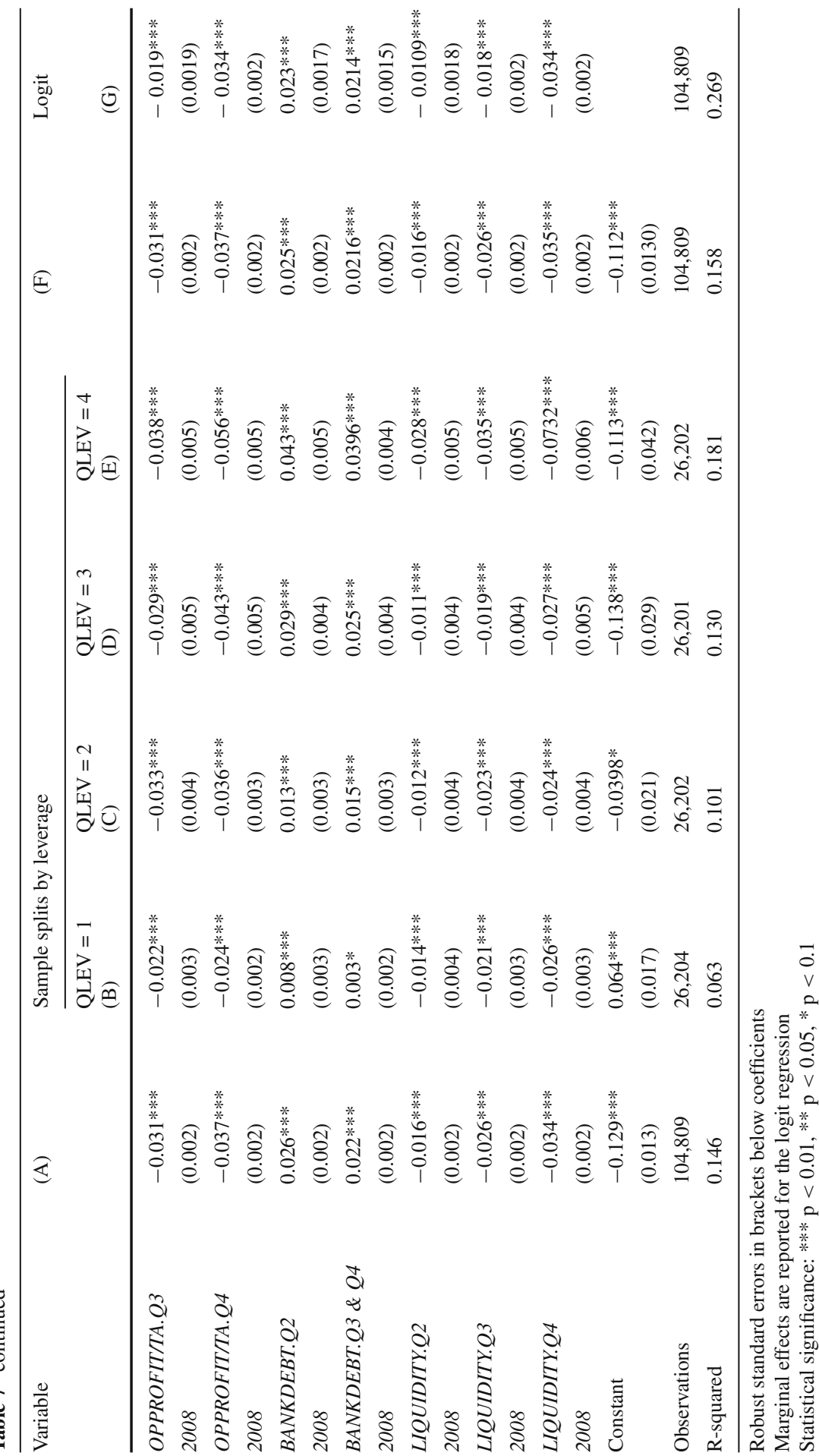




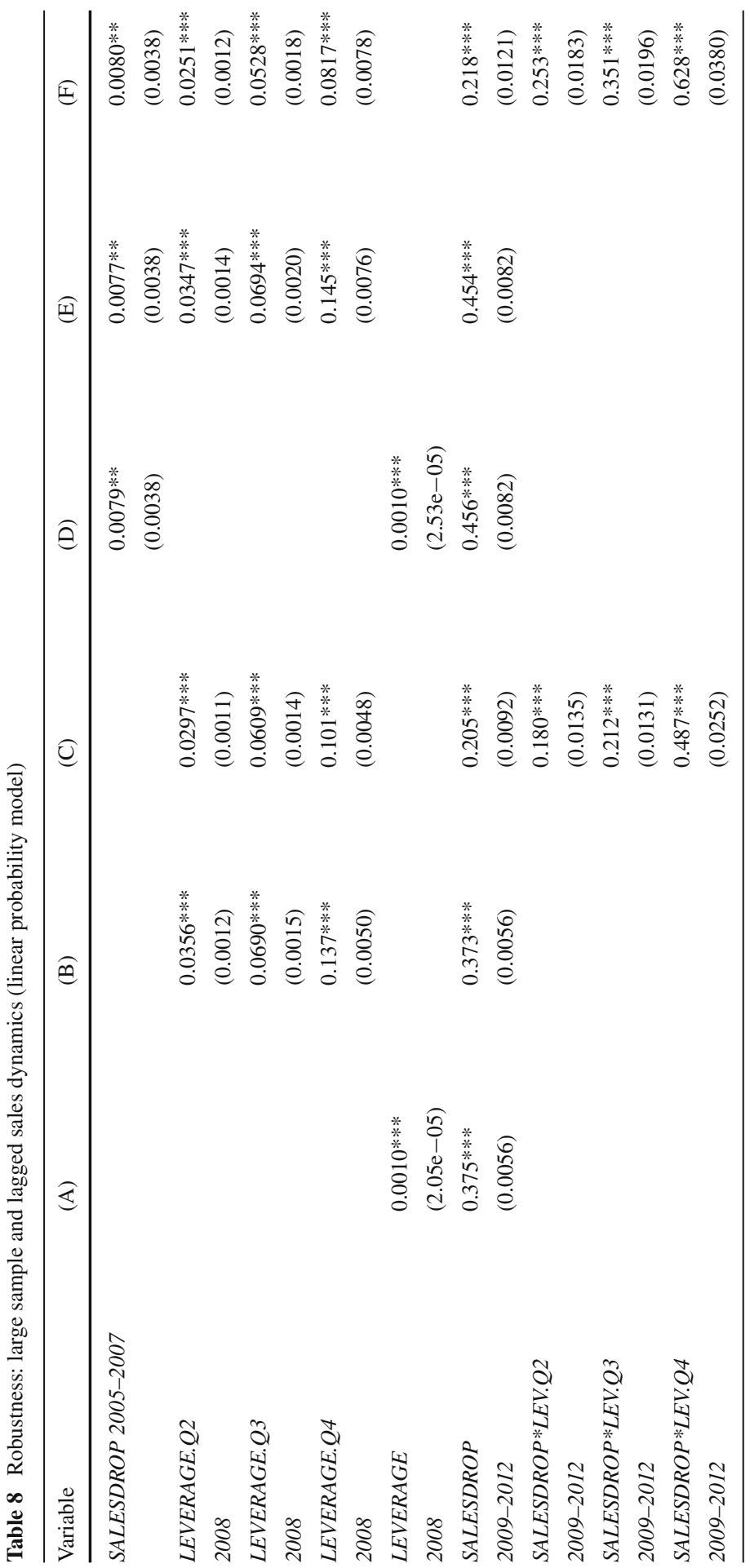




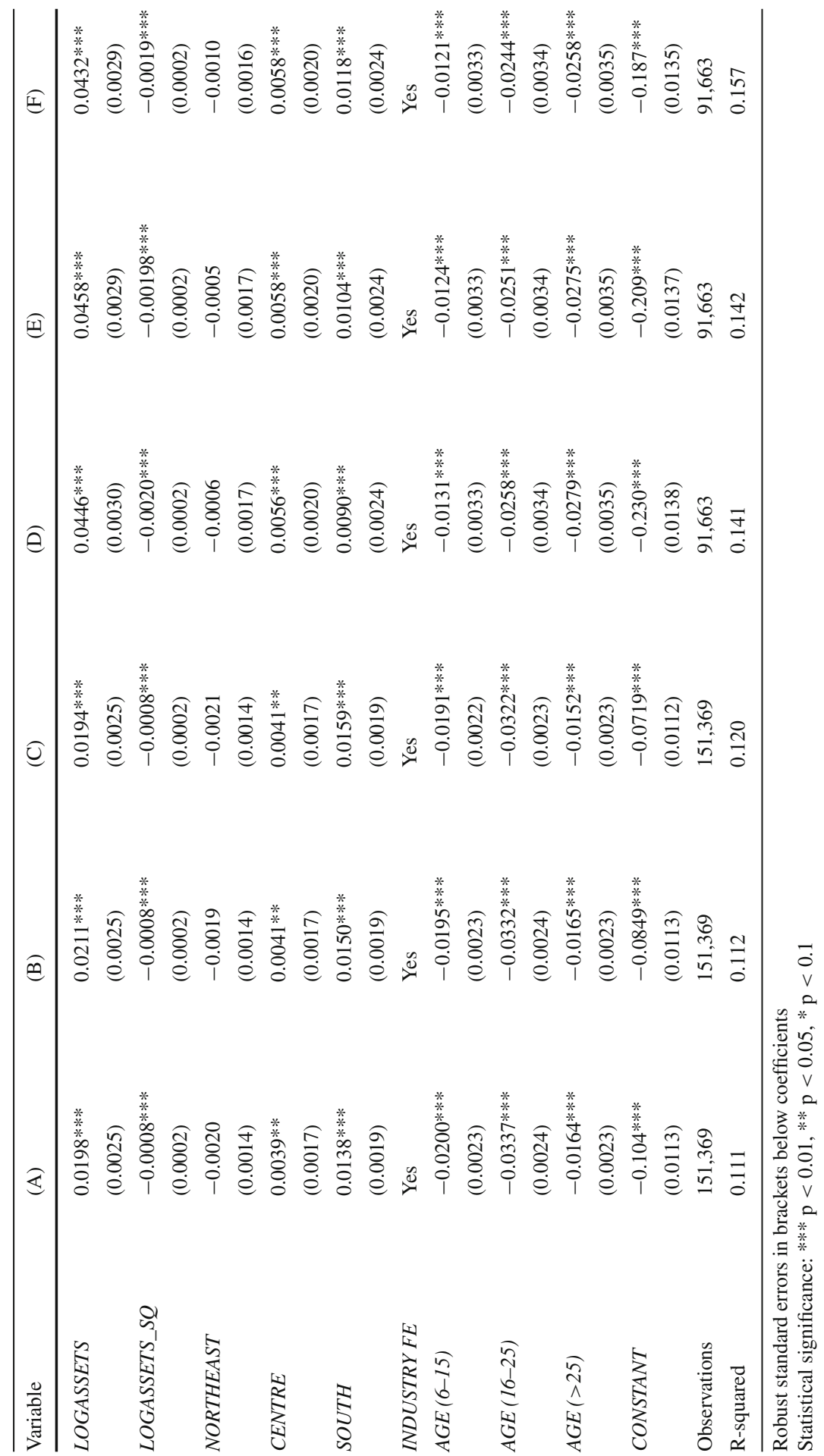




\section{Further Tests and Discussion of Results}

\subsection{Further Tests}

In this section we discuss some tests aimed at better understanding the differences across firms that might correlate with the level of initial leverage. Table 10 shows the 2005-2007 change in operating profits, sales and leverage for firms in each of the 2008 leverage quartiles. The mean growth rate of operating profits is very similar across the four quartiles. Instead, sales growth is faster for firms that have high leverage in 2008. Firms in the low quartile of leverage experience the slowest growth of debt before the crisis, while those in the top quartile have the fastest growth. Their expansion was supported by debt rather than by equity, and the increasing leverage was not having an impact on profitability since sales were going well.

This descriptive evidence could be affected by industry-specific factors. In particular, the construction industry was growing rapidly as collateral values were going up. We ran a simple regression of the 2008 level of leverage on firm size, age, industry dummies and the pre-crisis sales growth. The results, not reported for the sake of brevity, show that the change in sales has a positive coefficient, consistent with the descriptive statistics. Conditional on the demographic characteristics of firms, firms that were growing faster during the boom reached higher leverage before the recession. Hence, it is difficult to argue that they were poor performing or declining businesses.

We also studied how leverage and debt evolved during 2008-2012 by quartile of initial leverage. We ran a simple regression of the change of leverage on dummies for the leverage quartiles, dummies for the quartiles of operating profitability (OPPROFIT/TA), firm size, industry dummies and regional dummies. The results, reported in Table 11, show that firms that were in the third and fourth quartiles of leverage (higher leverage) in 2008 reduced leverage faster than the other firms in the subsequent period. The reduction was the result of both a faster increase in equity and a greater contraction of debt. The coefficients of the dummies for the profitability quartiles show that more profitable firms reduced their leverage more than less profitable firms, as expected, by increasing equity faster than debt.

\subsection{Discussion of Results}

The finding that leverage increases default is not new in the literature but we show that leverage has an independent effect, controlling for performance and for the size of the adverse shock that hit the firm during the economic contraction. What are the possible sources of this effect? Our analysis is based on a reduced-form model so it is not suitable to understand the channels through which leverage affects insolvency. Nonetheless, we can gain some insights on the possible mechanisms from exploring the patterns in the data.

Mechanically, financial distress occurs because firms with a high initial level of debt cannot meet their payments when operating revenues drop. In our data D firms have a much higher share of EBITDA absorbed by interest payments than ND firms even before the 2008 recession (2-3 times higher; Table 3 ). The fact that illiquidity 


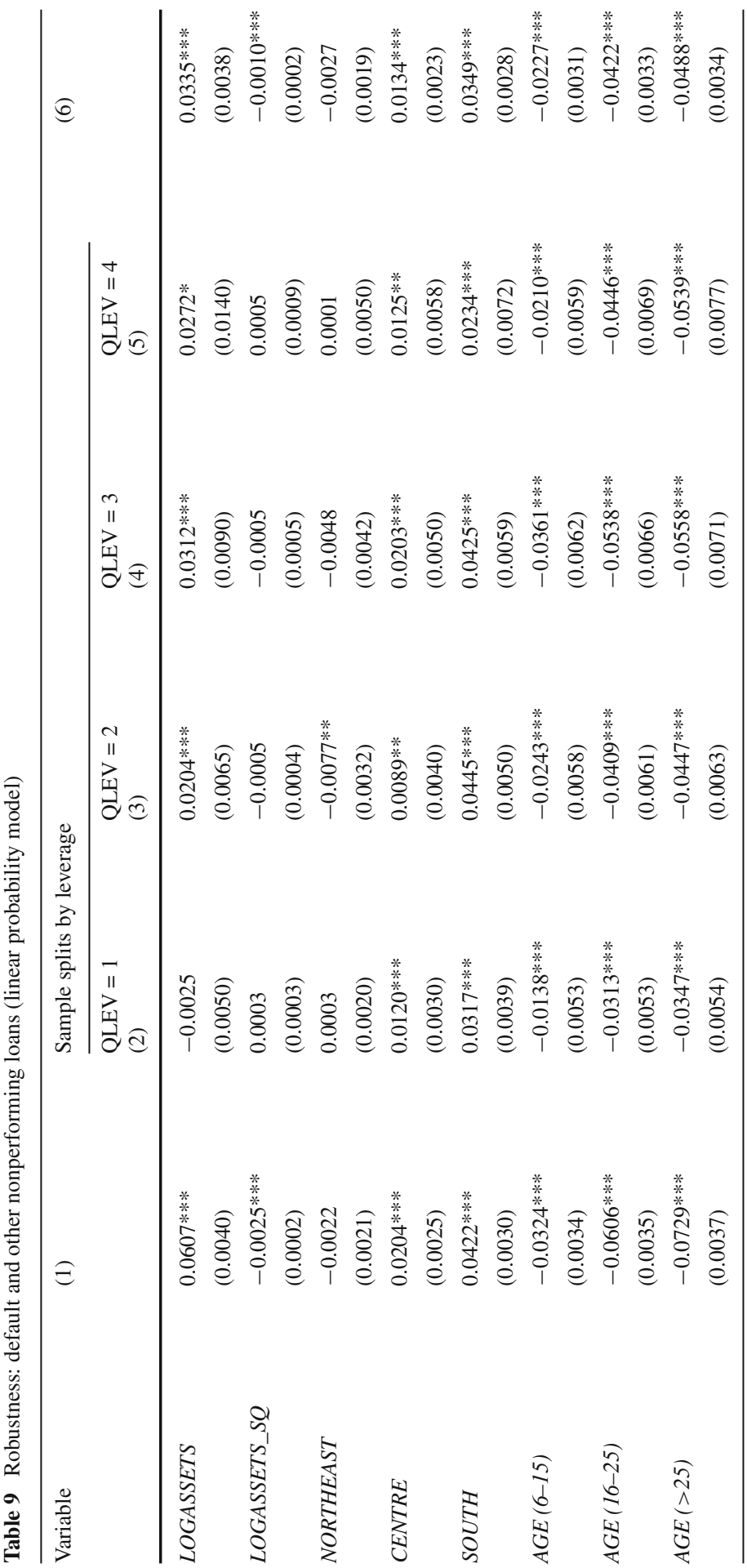




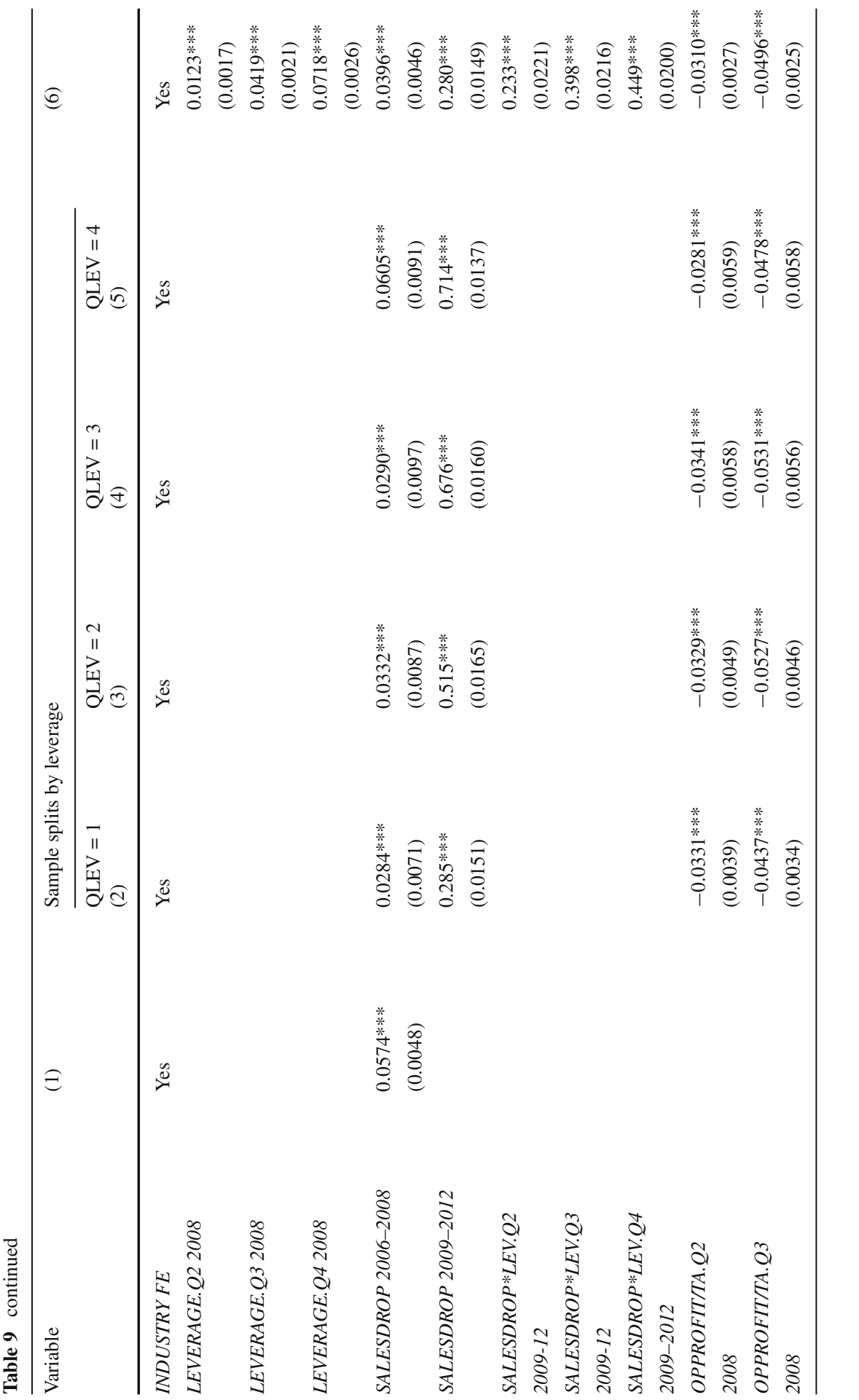




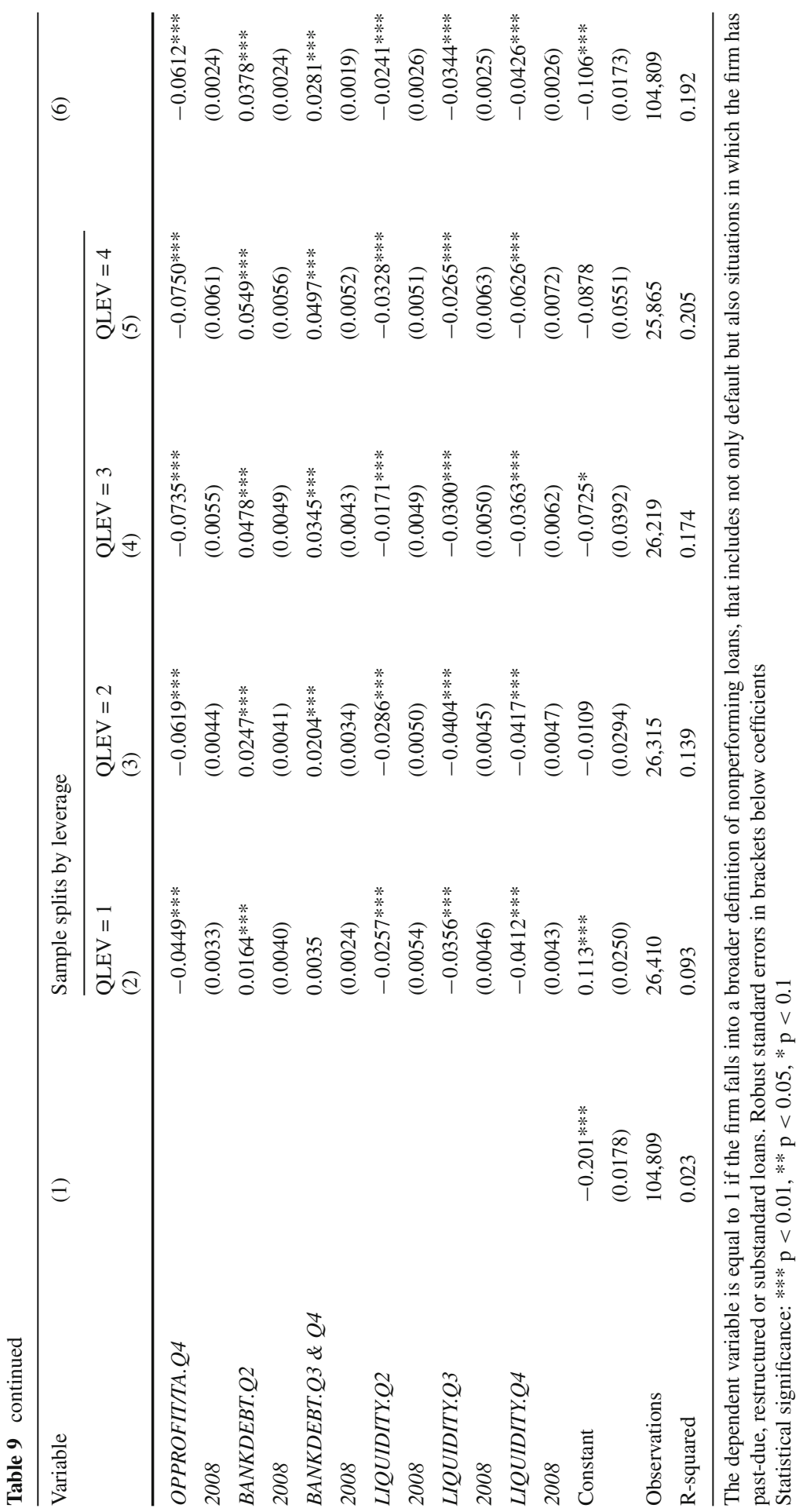


Table 10 Robustness: firms performance in the period 2005-2007, by quartile of leverage in 2008

\begin{tabular}{llll}
\hline & $\begin{array}{l}\text { SALES } \\
\text { growth rate } \\
\text { 2005-2007 (1) }\end{array}$ & $\begin{array}{l}\text { OPPROF/TA } \\
\text { growth rate } \\
\text { 2005-2007 (2) }\end{array}$ & $\begin{array}{l}\text { LEVERAGE } \\
\text { growth rate } \\
\text { 2005-2007 (3) }\end{array}$ \\
\hline LEVERAGE.Q1 (2008) & 0.11 & 0.13 & 0.03 \\
Observations & 22,811 & 20,901 & 19,913 \\
LEVERAGE.Q2 (2008) & 0.12 & 0.13 & 0.09 \\
Observations & 22,638 & 20,424 & 22,036 \\
LEVERAGE.Q3 (2008) & 0.14 & 0.12 & 0.06 \\
Observations & 21,986 & 19,674 & 21,648 \\
LEVERAGE.Q4 (2008) & 0.17 & 0.13 & 0.06 \\
Observations & 20,741 & 17,743 & 20,489 \\
\hline
\end{tabular}

(1) Growth rate of sales in 2005-2007, yearly mean. (2) Growth rate of gross operating profit divided by total assets in 2005-2007, yearly mean. (3) Growth rate of leverage (financial debt divided by the sum of financial debt and equity) in 2005-2007, yearly mean

forces default may be an efficient response if the firm is no longer economically viable. However, it is not obvious that a drop in sales is reflecting a permanent change in the economic viability of the firm, i.e. financial distress might not necessarily coincide with economic distress.

In the absence of perfect capital markets highly indebted firms may face financing constraints that prevent them from investing (Myers 1977). During a recession, firms that are more financially constrained because of high leverage might have more problems in reacting to the adverse environment and may end up being forced to exit as a result of underinvestment.

A second explanation is that leverage could influence the performance of the firm directly because clients or (suppliers) do not want to have transactions with a firm that is likely to fail. Opler and Titman (1994) find that highly leveraged firms lose substantial market share to their less leveraged competitors in industry downturns.

In our data the correlation between the drop in sales during the downturn and initial leverage is low (0.09). The joint distribution of the two variables shows that they are independent. There are only slightly more firms with a large drop in sales among those with high leverage.

Since we include a control for the drop in sales in the regression, we should interpret the estimated coefficient of leverage as the independent effect on default, controlling for possible effects that the financial structure might have through sales. While this independent effect of leverage on default is not inconsistent with optimal liquidation since many firms that had expanded when their prospects were good are likely to have become economically distressed, our finding of an interaction effect between leverage and the drop in sales is consistent with the financing constraints channel. Firms that face the same drop in sales, controlling for initial operating profitability, tend to default more frequently if they have higher leverage. We observe that debt declines faster during the economic contraction for firms that had higher initial leverage, but we also observe that equity increases more for these firms. Although this pattern is consistent with 
Table 11 Equity, debt and leverage growth rate over the period 2008-2012
Standard errors in parentheses $* * * \mathrm{p}<0.01, * * \mathrm{p}<0.05$ $* \mathrm{p}<0.1$

\begin{tabular}{|c|c|c|c|}
\hline Variables & $\begin{array}{l}\text { (2) } \\
\text { equity_gr }\end{array}$ & $\begin{array}{l}\text { (4) } \\
\text { debt_gr }\end{array}$ & $\begin{array}{l}\text { (6) } \\
\text { lev_gr }\end{array}$ \\
\hline LEVERAGE.Q2 & $-0.00428 * *$ & -0.00161 & $0.00855^{* * *}$ \\
\hline 2008 & $(0.00185)$ & $(0.00171)$ & $(0.00197)$ \\
\hline LEVERAGE.Q3 & 0.00162 & -0.00246 & $-0.00868 * * *$ \\
\hline 2008 & $(0.00188)$ & $(0.00172)$ & (0.00198) \\
\hline LEVERAGE.Q4 & $0.0126 * * *$ & $-0.00988 * * *$ & $-0.0235 * * *$ \\
\hline 2008 & $(0.00202)$ & $(0.00176)$ & $(0.00203)$ \\
\hline OPPROFIT/TA.Q2 & $0.0539 * * *$ & -0.00150 & $-0.0130 * * *$ \\
\hline 2008 & $(0.00192)$ & $(0.00168)$ & $(0.00181)$ \\
\hline OPPROFIT/TA.Q3 & $0.115^{* * *}$ & -0.000769 & $-0.0248 * * *$ \\
\hline 2008 & $(0.00194)$ & $(0.00169)$ & $(0.00183)$ \\
\hline OPPROFIT/TA.Q4 & $0.205 * * *$ & $-0.00715^{* * *}$ & $-0.0493 * * *$ \\
\hline 2008 & $(0.00203)$ & $(0.00178)$ & $(0.00195)$ \\
\hline INDUSTRY FE & Yes & Yes & Yes \\
\hline LOGASSETS & $\begin{array}{l}0.0361 * * * \\
(0.00354)\end{array}$ & $\begin{array}{l}-0.0208 * * * \\
(0.00313)\end{array}$ & $\begin{array}{l}-0.0232 * * * \\
(0.00344)\end{array}$ \\
\hline LOGASSETS_SQ & $\begin{array}{l}-0.00184 * * * \\
(0.000210)\end{array}$ & $\begin{array}{l}0.000758 * * * \\
(0.000186)\end{array}$ & $\begin{array}{l}0.000886^{* * * *} \\
(0.000205)\end{array}$ \\
\hline NORTHEAST & $\begin{array}{l}0.000689 \\
(0.00168)\end{array}$ & $\begin{array}{l}-0.00505^{* * * *} \\
(0.00149)\end{array}$ & $\begin{array}{l}-0.00219 \\
(0.00162)\end{array}$ \\
\hline CENTRE & $\begin{array}{l}0.00121 \\
(0.00190)\end{array}$ & $\begin{array}{l}0.0176 \text { *** } \\
(0.00168)\end{array}$ & $\begin{array}{l}0.000710 \\
(0.00182)\end{array}$ \\
\hline SOUTH & $\begin{array}{l}0.00541 * * * \\
(0.00206)\end{array}$ & $\begin{array}{l}0.0200 * * * \\
(0.00183)\end{array}$ & $\begin{array}{l}-0.00253 \\
(0.00197)\end{array}$ \\
\hline CONSTANT & $\begin{array}{l}-0.200 * * * \\
(0.0160)\end{array}$ & $\begin{array}{l}0.126 * * * \\
(0.0141)\end{array}$ & $\begin{array}{l}0.153 * * * \\
(0.0155)\end{array}$ \\
\hline Observations & 95,542 & 95,659 & 92,936 \\
\hline R-squared & 0.115 & 0.022 & 0.012 \\
\hline
\end{tabular}

financing constraints being tighter for more indebted firms, it could also be explained by firms rebalancing their financial structure after an increase in bankruptcy costs, as predicted by the trade-off theory of optimal leverage (Myers 1977). We cannot draw any conclusion since we are unable to separate demand (firms choose to reduce leverage) from supply (banks cut credit).

\section{Conclusions}

Using a statistical model we estimate the effect of leverage on the probability that a firm defaults on its bank loans in a very large sample of Italian firms, mostly privately held. Our results show that the variable that better explains firm default during a period of economic contraction is the drop in sales. Controlling for the drop in sales, 
initial leverage has a substantial influence on the probability of default. The effect of leverage is twofold. It raises the default probability for any given drop in sales, but it also increases the sensitivity of the default probability to the shock to sales. Our results support the conjecture that the degree of indebtedness of firms plays a role in financial stability because it amplifies the adverse impact of a real shock on firm solvency and, through this channel, on banks' health. This finding is consistent with different mechanisms relying on financial frictions through which leverage could affect default. We leave to further analysis their identification. Our simple empirical model is not suitable to single them out.

\section{References}

Altman EI (1968) Financial ratios, discriminant analysis and the prediction of corporate bankruptcy. J Financ 23:589-609

Altman EI, Sabato G (2007) Modeling credit risk for SMEs: evidence from the US market. Abacus 43(3):332-357

Bank of Italy (2014) Annual report on 2013. www.bancaditalia.it

Behr P, Güttler A (2007) Credit risk assessment and relationship lending: an empirical analysis of German small and medium-sized enterprises. J Small Bus Manag 45(2):194-213

Berger AN, Udell G (2004) The Institutional Memory Hypothesis and the Procyclicality of Bank Lending Behavior. J Financ Intermed 13(4):458-495

Blume M, Lim F, MacKinlay C (1998) The declining credit quality of U.S. Corporate Debt: myth or reality? J Financ 53:1389-1413

Bonfim D (2009) Credit risk drivers: evaluating the contribution of firm level information and of macroeconomic dynamics. J Bank Financ 33:281-299

Campbell J, Hilscher J, Szilagyi J (2008) In search of distress risk. J Financ 63:2899-2939

Carling K, Jacobson T, Lindé J, Roszbach K (2007) Corporate credit risk modeling and the macroeconomy. J Bank Financ 31:845-868

Chava S, Jarrow R (2004) Bankruptcy prediction with industry effects. Rev Financ 8:537-569

Dell' Ariccia G, Marquez R (2006) Lending booms and lending standards. J Financ 61(5):2511-2546

Fidrmuc J, Hainz C (2010) Default rates in the loan market for SMEs: evidence from Slovakia. Econ Syst 34:133-147

Graham JR, Hazarika S, Narasimhan K (2011) Financial distress in the great depression. NBER Working Paper No. 17388

Hoetker G (2004) Confounded coefficients: extending recent advances in the accurate comparison of logit and probit coefficients across groups. University of Illinois at Urbana Champaign Working Paper, October 22, 2004

Kaplan RS, Urwitz G (1979) Statistical models of bond ratings: a methodogical inquiry. J Bus 52(2):231-261

McCann F, McIndoe-Calder T (2012) Determinants of SME loan default: the importance of borrower-level heterogeneity. Working Paper, Central Bank of Ireland

Merton R (1974) On the pricing of corporate debt: the risk structure of interest rates. J Financ 29:449-470

Molina CA (2005) Are firms underleveraged? Default probabilities. J Financ 60(3):1427-1459

Myers SC (1977) Determinants of corporate borrowing. J Financ Econ 5:146-175

Ohlson J (1980) Financial ratios and the probabilistic prediction of bankruptcy. J Account Res 18:109-131

Opler TC, Titman S (1994) Financial distress and corporate performance. J Financ 49:1015-1040

Saurina J, Jimenez G (2006) Credit cycles, credit risk, and prudential regulation. Int J Central Bank 2:65-98

Shumway T (2001) Forecasting bankruptcy more accurately: a simple hazard model. J Bus 74:101-124

Tabachnick BG, Fidell LS (1996) Using multivariate statistics. HarperCollins College Publishers, New York 